\title{
Auto-pop: Vášnivé a osudové spojení automobilu a populární hudby
}

\author{
Markéta Polákován ${ }^{1}$ Adéla Šeredová Purschová ${ }^{2}$ \\ ${ }^{1}$ Lokální a regionální studia, Sociologický ústav Akademie věd České republiky, v.v.i. \\ ${ }^{2}$ Katedra kulturologie Filozofické fakulty Univerzity Karlovy v Praze
}

Do redakce doručeno 25. srpna 2012; k publikaci přijato 12. listopadu 2012

\section{AUTO-POP: PASSIONATE AND FATAL CONNECTION BETWEEN CAR AND POP MUSIC}

ABSTRACT The subject of this paper is an analysis of automobile theme in pop music. Automobile overcomes its utilitarian function and becomes the subject of the desire, worship and social prestige more than other artefacts for everyday use. It is not extraordinary, that automobile also has entered music and we can find the automobile theme in many songs texts or video clips, where it appears in several key and recurrent levels. One particular chapter of this paper concerns how music influences driving or what automobiles music icons own. The end of this paper concerns some of music experiments with automobile, where it has function of music instrument.

KEY WORDS automobile; music; songs texts; video clips; music icons

ABSTRAKT Předmětem studie je analýza motivu automobilu v populární hudbě. Automobil překračuje svoji utilitární funkci a stává se předmětem touhy, uctívání i sociální prestiže více než jiné předměty každodenního užívání. Nelze se tedy divit, že vstoupil i na pole hudby a jeho motiv můžeme najít nejen v textech písní či hudebních videoklipech, v nichž je možné sledovat několik ústředních a opakujících se témat. Samotnou kapitolu tvoři vliv hudby na řízení automobilu či fenomén slavných vlastníků výjimečných vozů. $V$ závěru studie představíme některé z experimentů, ve kterých se pod rukou umělců sám automobil stal hudebním nástrojem.

KLÍČOVÁ SLOVA automobil; hudba; texty písní; videoklipy; hudební ikony

\section{HUDBA A ŘÍZENÍ AUTOMOBILU}

Hudbu lze považovat za jedno z nejemocionálnějších umění. Stává se účinným prostředkem k vyvolání vzpomínek na různá životní období, osoby či místa, které měly pro každého jedince zvláštní význam, zejména když se jednalo o situace se silným citovým prožitkem. Vedle toho hraje roli hlasitost a tempo hudby. S hlasitou a rychlou hudbou si posluchač asociuje jevy, v nichž je obsažena silná energie, a proto je na tento druh hudby odpovídající emocionální reakcí excitace. Jedním $\mathrm{z}$ cílů regulace emocí pomocí hudby je touha cítit se lépe - mít dobrou náladu (hédonická motivace). Dochází ale $\mathrm{k}$ případům, kdy hudba naopak udržuje posluchače ve špatné náladě nebo ji dokonce o něco zhorší. Podle amerického muzikolo- ga Leonarda B. Meyera (1918-2007) však při poslechu hudby neprožíváme skutečné emoce, hudba pouze popisuje emoci, o které soudí, že ji daný úsek hudby vyvolává (podle Franěk 2005, 173). Posluchač má obecnou představu o emocionálním působení hudby a očekává, že sám bude tímto způsobem na hudbu reagovat, a proto již při prvních hudebních tónech posluchačovo očekávání spouští určitou emocionální reakci doprovázenou příslušnými fyziologickými změnami (Franěk 2005, 173). Podle britského psychologa Johna A. Slobody (narozen 1950) hudba nevytváŕí ani nemění emoce, ale spíše umožňuje přístup k prožitku emocí, které člověk již na určitém stupni prožívá, ale není si jich zcela vědom (Franěk 2005, 174). V poslední době se rovněž objevují diskuse na téma, zda dlouhodobý poslech určitých druhů hudby nevede k agresiv- 


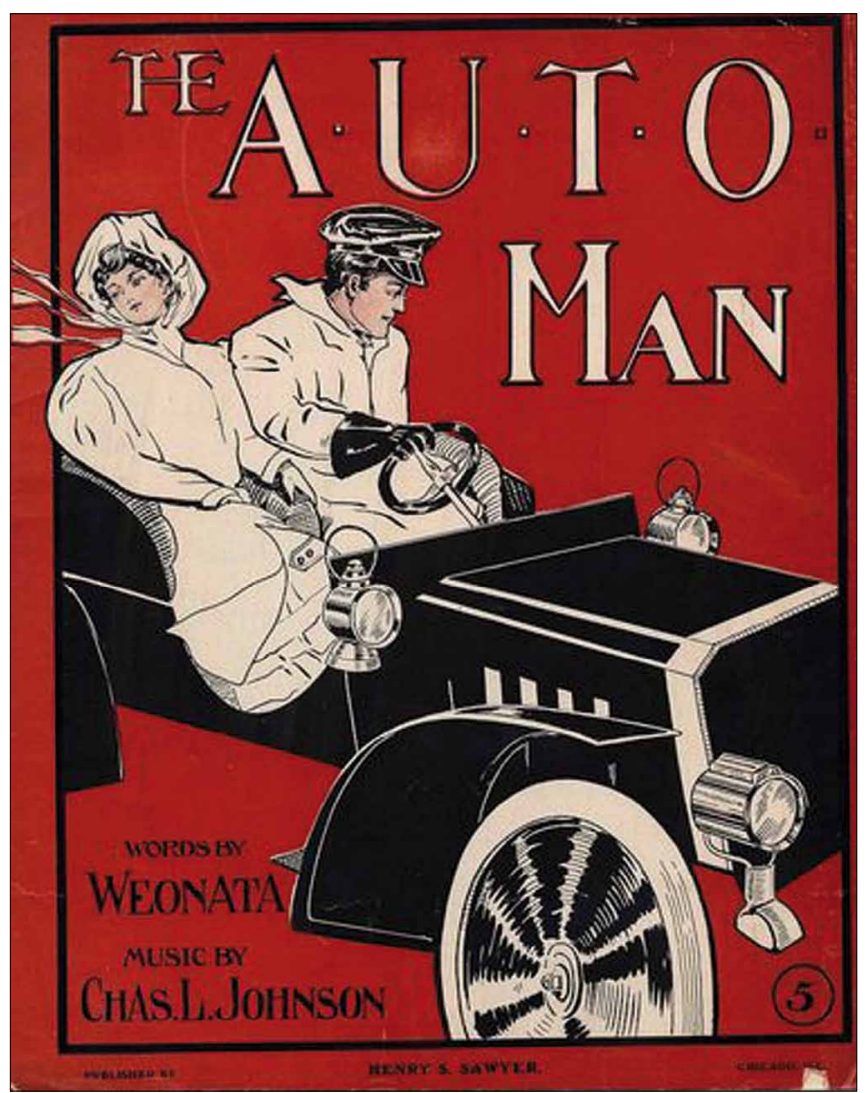

Obr. 1. Prestiž vlastnictví automobilu ukazovala píseň The Auto Man z roku 1906. Pramen: http://amhistory.si.edu/onthemove/collection/image_831.html

nímu či asociálnímu chování. Nejčastěji se v této souvislosti hovoří o rockové hudbě či o heavy metalu a rapu. Např́ílad výzkum kanadských psychologů Davea Mirandy a Michela Claese $(2007,2009)$ ukázal, že obliba rapu byla obecně celkově spjata s deviantním chováním (násilí, krádeže, drogy). Podobně také výzkumy zaměřené na hudbu žánru techno a reggae ukázaly souvislost $s$ častějším požíváním alkoholu a drog. Hudební nahrávky těchto žánrů mnohdy dávají alkoholu a ilegálním drogám odlehčující či humorizující tón, a tak $\mathrm{v}$ očích posluchačů mohou snižovat závažnost užívání těchto návykových látek (Gruber a kol. 2005).

O tom, jestli hudební preference vyvolává antisociální chování, nebo jej spíše následuje, se však stále vedou mezi odborníky debaty. V současné době je automobil možná nejčastějším místem pro poslech hudby. Hudební přehrávač je dnes považován za základní vybavení automobilu a tak se nabízí otázka působení hudby na emoci při řízení. První pokusy s instalací rádií do automobilů se datují do 30 . let minulého století, kdy amatérští nadšenci upravovali běžná rádia a montovali si je do svých vozů. Jedno $\mathrm{z}$ prvních komerčně úspěšných autorádií v historii bylo autorádio „Motorola“. To bylo představeno v roce 1930 společností Galvin Manufacturing Corporation. Autorem pojmenování autorádia, které ve svém názvu vyjadřovalo „Zvuk v pohybu“, byl Paul Galvin. Rádio Motorola stálo přibližně 120 dolarů včetně příslušenství a montáže, což byla

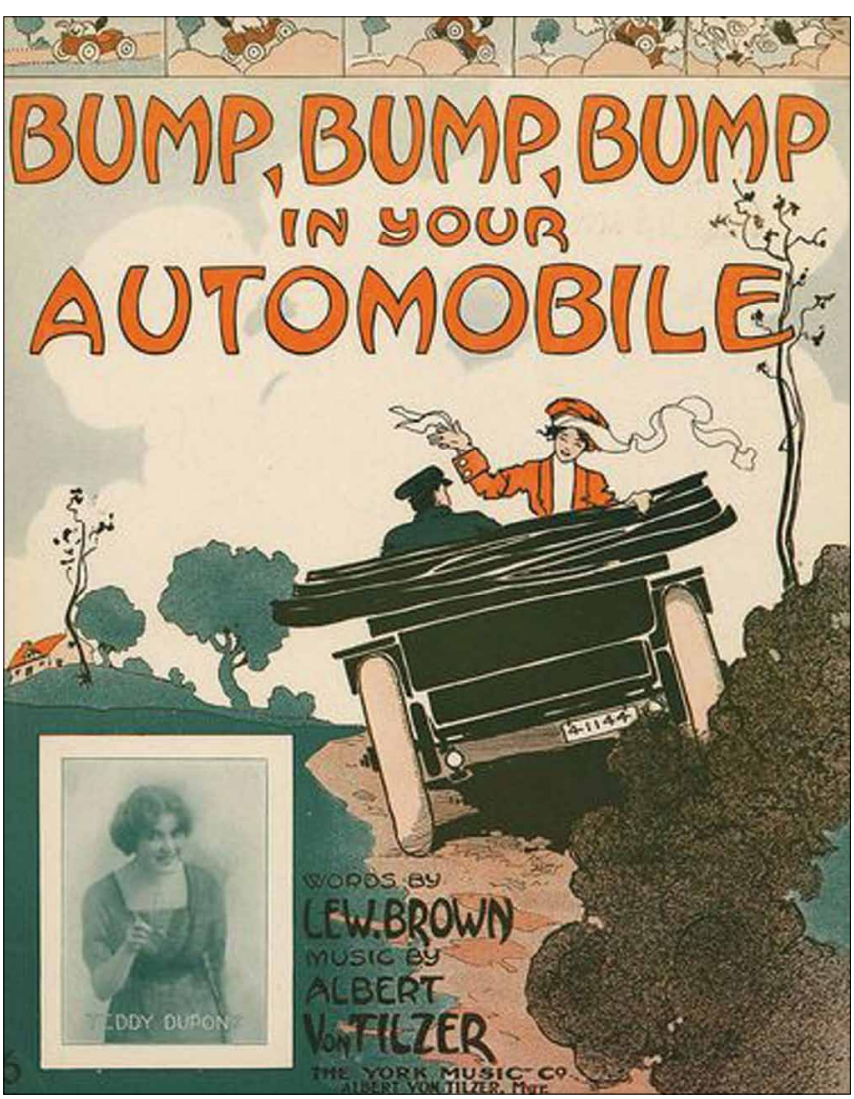

Obr. 2. Humorně laděná píseň Bump, Bump, Bump in Your Automobile vznikla v roce 1912. Pramen: amhistory.si.edu/onthemove/collection/image_830.html

ve srovnání s konkurencí, která vyráběla na míru navržená zařízení, velice příznivá cena.

V souvislosti s automobily se mnohdy uvádí, že lidé, kteří poslouchají při řízení divokou a hlasitou hudbu, jsou náchylnější k nehodám více než ti, kteří poslouchají klidnější skladby. $S$ rostoucím tempem a častým střídáním akordů pak mají lidé větší tendenci jezdit rychleji (Brodsky 2001, 237) a při jízdě riskovat (Havlík 2005, 178). Je prokázáno, že pokud řidič poslouchá př́liš dynamickou hudbu, aniž by si to uvědomoval, má podvědomě tendenci jezdit ve stejném stylu. Hudba však může působit i pozitivně - zejména během monotónní jízdy, kdy může pomoci zažehnat únavu a povzbudit pozornost. At' už tedy působí poslech hudbu pozitivně či negativně, rozhodně nelze vliv hudby při řízení automobilu podceňovat, jako jeden z faktorů, který působí na náladu a chování za volantem.

\section{PÍSNĚ O AUTECH}

Stěžejním tématem této studie je však zejména analýza textů v písních populární hudby, které se dotýkají motivu automobilu. Automobil je předmětem touhy, uctívání i součástí prestiže jednotlivých lidí více než jiné každodenní předměty. Nelze se tedy divit, že lidé svoji vášeň $\mathrm{k}$ autům přenesli do hudby a automobil tak zaujal významné postavení v tex- 
tech mnoha hudebních skupin a zpěváků. Téma cestování a dopravy hrálo významnou roli $\mathrm{v}$ šírení populární hudby zejména $\mathrm{v}$ prostorově rozlehlých Spojených státech amerických (Davidson 2012). Koncem 19. století to byly zejména vlaky a rozsáhlá sít železnic, jejichž prostřednictvím mohli hudebníci cestovat mezi městy. Brzy se však začala prosazovat dominantní pozice automobilů. Jejich rychlost, krása a síla se stala předmětem opěvování mnoha hudebníků. V prvních textech byl kladen důraz zejména na vyjádření pocitu, že vlastnictví automobilu bylo prestižní a módní záležitostí, tak jak to naprríklad ukazovala $v$ roce 1906 píseň The Auto Man (Davidson 2012) (obr. 1). Některé písně se vyrovnávaly s faktem stinných stránek automobilů - jejich poruchami, špatnými silnicemi, nehodami. Kurátorka expozice America on the Move (česky Amerika v pohybu) z washingtonského Muzea americké historie Janet Davidson jako prríklady těchto písní uvádí humorně laděné Get Out and Get Under z roku 1913 či Bump, Bump, Bump in Your Automobile z roku 1912 (obr. 2). V Get Out and Get Under je nastíněna frustrace zamilovaného páru, když se muž dívku snad „tucetkrát pokoušel obejmout a políbit, ale ten zatracený motor stále vynechával“. V Bump, Bump, Bump in Your Automobile zase hlavní protagonista př́běhu Willie Green bere svoji snoubenku Molly May na projíždku automobilem. Cestu ale komplikuje kamenitá cesta a vystrašená Molly vykřikuje: „Přestaň jezdit po těch kopcích. Zastav! Podívej se, najíždíme na kámen! (Oh, Willie, zlato, zařad’ správnou rychlost!) Vyskoč, vyskoč, vyskoč, vyskoč ze svého automobilu." Stejně tak je v této písni zdůrazněno, že ženy byly přitahovány muži, kteří vlastnili automobil: „Molly May prohlásila, že miluje Willieho Greena. A nejvíc ze všeho na něm miluje tu mašinu. " Automobil byl pak také stále více zmiňován $\mathrm{v}$ souvislosti $\mathrm{s}$ namlouváním párů. Již z roku 1899 pochází píseň Alfreda Dixona s názvem Love in an Automobile, která vyjadřovala, že nápadník měl u dívek větší úspěch, když jim navrhl: „Nechtěla bys jet na líbánky v útulném automobilu? Když slyšela tuto nabídku, bez obav po ní s radostí skočila. Odpověděla pouze otázkou: Oh, řekni, chlapče, kdy?" Další podobně laděné písně, které v sobě nesly motiv dvoření se dívce skrze automobil, byly např́klad Take Me Out for a Joy-Ride či Come Take a Ride in My Auto (Hillstrom - Hillstrom 2006, 239). V některých písních byly automobily a ženy shodně považovány za objekty touhy (napríklad The Automobile Girl, The Motor Girl, My Auto Lady či Motor Maid). Muži, kteří vlastnili automobily, jež pak mohli využít k navázání intimních vztahů, ale také mnohdy vyvolávali ve společnosti úzkost kvůli obavám z morálního vývoje svobodných mužů a žen a jejich př́padného nemanželského sexu (Davidson 2012). Některé písně vyloženě varovaly před nebezpečím, které plynulo z pozvání na projíždku automobilem - typickým prŕkladem je Keep Away from the Fellow Who Owns an Automobile nebo Come Take a Trip in My Automobile (1912), ve které hlavní protagonista písně Billie Jones obtěžuje ženy na ulici a nabízí jim, aby se s ním projely v autě: „Nepojedeme daleko, jen kousek od bulváru. Je tu místo pro Vás i mě, štastný, štastný pár budeme. Dovezu Vás domů v osm nebo v devět. Pojdte a budeme se mít skvěle.“

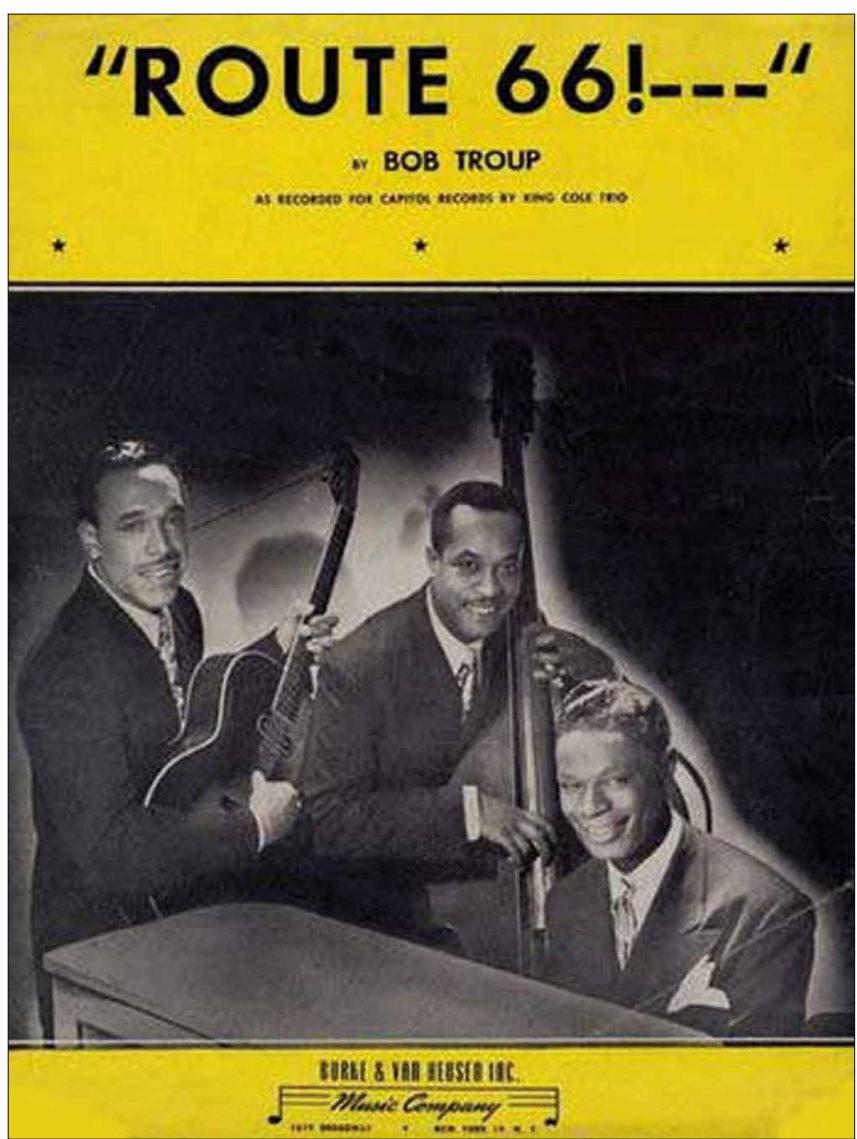

Obr. 3. Slavný singl Route 66. Pramen: http://en.wikipedia.org/wiki/File:Kingcoletrioroute66.jpg

Nezodpovědný Billie ale slib nedodrží a dívky doveze domů až ve tři ráno. A tak píseň končí větou: „Utíkají, když vidí, že se blíží se svým úžasným a skvělým automobilem. “ Z roku 1927 pak pochází píseň Get Em in a Rumble Seat, která otevřeně boří veškeré tradiční namlouvací procesy. Tzv. „rumble seat“ představovalo sedadlo, které se mohlo rozložit v zadní části automobilu. Chlapcům se pak v této písni radí: „Ted se jenom přitulit, a oh, chlapče! Jak se cítíš? Nemusíš se už bát, když je (dívky) miluješ, už nejsi za volantem. Je to přitažlivé být na zadním sedadle. Je to skvělý vynález..." Předmětem obsahu písní se stávalo i automobilové palivo, jak ukazuje například píseň Gasoline z roku 1913. Slova této písně opěvují ctnosti benzinu, který se stal pro mnohé lidi nejvzácnějším darem, za který neváhali utratit poslední dolary ze svého platu: „Benzin, benzin, všude kam jdete, tak ho cítíte. Zdá se, že to vykřikuje každý motor. Benzin, benzin! Je to volání, které se ozývá z Tvých snů. Benzin, benzin!“

Snad jedna $\mathrm{z}$ nejslavnějších písní o řízení automobilu je pak Route 66 (obr. 3). Když americký jazzový pianista, zpěvák a skladatel Nat King Cole (1919-1965) zpíval tuto píseň, zkomponovanou roku 1946 Bobbym Troupem (1918-1999), byla tato silnice důležitou dopravní tepnou spojující střed USA se západním pobřežím: „No, tak jestli tě někdy napadne vyrazit autákem na západ, jed' po té mé cestě, to je silnice - ta nejlepší, vem to přes Route 66. Jó, ta se táhne $\mathrm{z}$ Chicaga až 
do L.A. a to je víc než 2000 mil, vem to přes Route 66. "Troupa inspirovala $\mathrm{k}$ složení této písně jeho cesta $\mathrm{z}$ Pennsylvánie do Los Angeles. V jednom rozhovoru přiznal, že věta „vem to přes Route 66 “ (v originále „Get your kicks on Route 66“) $\mathrm{k}$ němu přišla snadno, stejně jako melodie celé písně, ale se zbytkem textu měl problémy. Ze zoufalství pak prázdná místa $\mathrm{v}$ textu písně zaplňoval názvy hlavních měst a obcí, na které cestovatel po Route 66 narazí. Původní verze od Colea byla mnohokrát přezpívaná a opakovaně se stávala oblíbenou hudební kulisou filmů ve scénách týkajících se jízdy autem a řízení. Mezi významnými interprety, kteří tuto píseň zařadili do svého repertoáru, byli např́klad Rolling Stones, Chuck Berry, Jerry Lee Lewis, Natalie Cole (dcera Nat King Cola), Van Morrison či Depeche Mode (viz http://www.r66.cz).

V následujícím textu není možné podstoupit analýze všechny písně, které se dotýkají automobilu, proto se v této studii zaměříme zejména na ty, které jsou podle našeho významu nejpodstatnější - at již z hlediska témat, jež se v nich objevovala, či významných interpretů, pro jejichž tvorbu byl motiv automobilu zásadní.

\section{Automobil jako téma}

U některých zpěváků či hudebních skupin se automobil stává opakujícím tématem, které je přenášeno do mnoha významových rovin. Několik písní o automobilu můžeme nalézt v tvorbě amerického zpěváka, skladatele a jednoho z průkopníků rock and rollu Chucka Berryho (narozen 1926). Např́iklad v písni Maybellene $\mathrm{z}$ roku 1955 vypráví příběh o dívce, která podvádí svého muže. Berry popisuje, jak se hlavní hrdina písně snaží Maybellene dostihnout ve svém Fordu V8, zatímco ona mu ujíždí s mužem v cadillacu: „Já a ten cadillac byli jsme na sebe nalepení. Maybellene, proč jsi nebyla upřímná? A znova ses začala chovat tak jako dřív?" Další Berryho píseň No Money Down (1955) je inspirována jeho př́íhodou z mládí, kdy si chtěl koupit své první auto - Ford V8, za který měl zaplatit 10 dolarů na ruku a pak každý měsíc splácet 5 dolarů. Tato píseň je podnícena nabídkami prodejců, jichž se mu dostávalo, když si kupoval několik svých prvních vozů. $\mathrm{V}$ písni nastiňuje proces výběru automobilu, včetně těch nejnáročnějších požadavků, které si původně stanovoval: „Chci posilovač řízení a výkonné brzdy. Chci silný motor... chci také klimatizaci a automatickou regulaci teploty." Tyto požadavky však neodpovídaly jeho finančním možnostem a musel se vzdát představ ohledně vlastnictví cadillacu či žlutého kabrioletu. $\mathrm{V}$ závěru písně pak po veškerém vyjednávání Berry prohlašuje: „Mám své auto. Mírím si to na silnici. Žádné peníze na ruku. Nemusím se bát, jestli rozbiju tenhle oprýskaný Ford.“

V písni You Can’t Catch Me z roku 1956 (k nejúspěšnějším coververzím této písně patři podání skupiny Rolling Stones či Johna Lennona ${ }^{1}$ ) Chuck Berry přináší oblíbené téma rychlého

1 John Lennon je s Chuckem Berrym díky této písni spojován i v negativnějším pohledu. Po té, co nahrál píseň Come Together byl vydavatelstvím Chucka Berryho obviněn z porušení autorských práv automobilu, který se může alespoň v jeho představách proměnit v létající stroj: „Koupil jsem si zbrusu nové na zakázku vyrobené vzdušné auto. Bylo to létající auto, se silným motorem a ukrytými kř́ídly. Zmáčkněte tlačítko a můžete jej slyšet létat. “ Berry svoje létající auto něžně pojmenovává Maybellene (stejně jako svoji výše zmiňovanou píseň z roku 1955): „Přilepí se jako med, bude má láska. Nejsladší věc, kterou jsem kdy viděl. Budu jí ŕíkat Maybellene." V roce 1964, v době kdy byl Chuck Berry ve vězení a skutečně tedy neměl kam jít, přichází s písní s názvem No Particular To Go. Ta má nádech nenaplněné potence noci, kdy hrdina písně není schopen povolit bezpečnostní pás své spolujezdkyně: „Nebylo žádné konkrétní místo kam jít, tak jsme zaparkovali u cesty na Kokomo. Noc byla mladá a měsíc jasný, tak jsme se rozhodli, že půjdeme na procházku. Umíte si představit, jak jsem se cítil? Nebyl jsem schopen rozepnout její bezpečnostní pás." V písní Dear Dad z roku 1965, která má formu dopisu syna otci, žádá syn, aby mu otec koupil nové auto: „Drahý tatínku, nerozčiluj se z toho, o co Tě chci požádat. Mohl bys mi k př́štímu semestru dát nové auto? Tohle už je k ničemu. Na široké dvouproudové silnici bych mohl stejně tak jít pěšky, jako řídit tenhle starý Ford." Syn vyjmenovává argumenty, kterými se snaží na otce zapůsobit - jeho původní automobil už je zastaralý, neovladatelný a nebezpečný. Celá píseň dostává další dimenzi, když se z poslední sloky dozvídáme, kdo vlastně onen syn je. „Tak tati pošli peníze. Podívej se, co vidím. Pokus se najít cadillac - šedesát dvojku či trojku. Prostě něco takového, s čím nebudeme muset mít obavy vyrazit na silnici. S láskou Tvůj milovaný syn Henry Junior Ford.“

Automobil je častým tématem také pro amerického folkového kytaristu a zpěváka Bruce Springsteena (narozen 1949). Snad v nejznámější Springsteenově písni na dané téma Pink Cadillac z roku 1984 (první akustická verze pochází z ledna $1982^{2}$ ) je podobně jako například v písni Little Red Corvette (obr. 7) či Mustang Sally (viz níže) cestování automobilem možné interpretovat jako metaforu pro sexuální aktivitu. Cadillac se zde stává nástrojem, kterým žena svádí muže -

$\mathrm{z}$ důvodu podobné melodie a textu s You Can't Catch $\mathrm{Me}$ - Lennon zpívá: „Here come ol' flattop, he come groovin’ up slowly’ a Berry „Here come a flattop, he was movin’ up with me“. Lennon to popřel $\mathrm{s}$ tím, že v jeho textu mají daná slova jiný význam. Nakonec Lennon musel slíbit, že natočí tři písně, na které pak vlastnil výhradní autorská práva vydavatel Berryho.

2 Vedle Springsteenova originálu existuje i několik „ženských verzi“ podání této písně. Americká zpěvačka Bette Midler (narozena 1945) plánovala zařadit píseň Pink Cadillac na svém turné v letech 1982-1983. Springsteen však zablokoval uvedení její verze s tím, že tato píseň není pro ženy. Nakonec Midler vydala v roce 1984 videozáznam z koncertů s názvem Art and Burst, kde píseň Pink Cadillac zazněla hned na začátku. Někdy je nesprávně označována za interpretku této písně rovněž americká zpěvačka Aretha Franklin (narozena 1942), která v písni Freeway of Love z roku 1985 používá podobné metaforické vyjádření spjaté s růžovým cadillacem jako Springsteen: „Vydáváme se na projiždku po dálnici lásky v mém růžovém cadillacu." V polovině 80 . let nahrála píseň Pink Cadillac také americká zpěvačka Natalie Cole (narozena 1950). 
podobně jako biblická Eva svedla Adama jablkem, láká žena muže na svůj růžový cadillac se sametovými sedačkami: „Dobře, a ted’ zpátky $\mathrm{k}$ Bibli. Pokušení vždycky přicházejí. Vždycky je tu něco lákavého. Někdo si dokáže uvědomit, že je v tom něco špatného. Fajn, svádějí Tě stř́brem, a svádějí Tě zlatem. A svádějí Tě rozkošemi, kterých se lidské tělo dokáže zdržet. Ř́iká se, že Eva pokoušela Adama jablkem, ale to není to, na co jsem skočil. Byl to její růžový cadillac." V některých částech písně se objevují prímé sexuální narážky - je to zejména věta: „Miluji Tě pro Tvůj růžový cadillac“, která mohla být vnímaná jako skrytý odkaz na vaginu. Stejně tak má erotický nádech věta: „Zlato, jsem zvědavý, co provádíš na zadním sedadle svého růžového cadillacu."

Springsteenova píseň Racing in The Street z roku 1978 vyjadřuje touhu amerických mužů po svobodě, kterou jim poskytuje řízení rychlých automobilů. Ústř̌ední postavou písně je muž, jehož stěžejní pýchou a radostí je Chevy Chevelle 69, kterou zrekonstruoval se svým kamarádem. S tímto automobilem jezdí mezi městy a závodí s ním za peníze proti ostatním závodníkům na severovýchodě Spojených států. Vypravěč v této písni rozlišuje lidi na ty, kteří se „vzdají života a postupně začínají pomalu umírat" a ty, kteří podobně jako on hledají další naplnění, což je $\mathrm{v}$ jeho př́padě pouliční závodění. Ve skutečnosti však může být toto závodění vnímáno jako prostředek úniku před zodpovědností (v kontrastu s niže uvedenou písní Tracy Chapman „Fast Car", kdy hlavní hrdina $\mathrm{k}$ odpovědnosti právě prostřednictvím rychlé jízdy směřuje). Prrítelkyně hlavního protagonisty ale jeho sny príiliš nesdílí, má o něho starosti a potýká se s mučivými depresemi: „Zírá do noci prázdnýma člověka, který nenávidí pro co se narodil.“ Příběh však končí nadějným zvoláním vypravěče, který se snaží pomoci dívce s bojem proti jejím démonům a dodat ji naději: „Dnes večer se miláčku vydáme $\mathrm{k}$ moři a smyjeme všechny hříchy $z$ našich rukou. “

Další píseň Bruce Springsteena z roku 1980 Cadillac Ranch je inspirovaná dílem umělecké skupiny Ant Farm, které se nachází u zbytků slavné silnice Route 66 na předměstí města Amarillo v severním Texasu. Na poli nedaleko hlavního tahu I-40 stojí řada deseti z poloviny do země zapuštěných cadillaců $\mathrm{z}$ let 1949-1963, které mají turistům připomínat zašlou slávu americké popkultury a pomíjivost ,života“ těchto legendárních automobilů. Neobvyklý monument byl vytvořen v roce 1974, původní jednobarevný nátěr je dnes pokryt stovkami barevných nápisů a obrazců, jež zde zanechávají mnozí návštěvníci: „Cadillac, Cadillac. Dlouhý a temný, lesklý a černý. Zapněte motor a nechte jej řvát. Vtrhněte na dálnici jako velký starý dinosaurus. James Dean v tomhle Mercury '49, Junior Johnson projiždí lesem v Karolíně̉, dokonce Burt Reynolds v tom černém Trans-Am, všichni se scházejí na Cadillac Ranch."

Springsteenova melancholická píseň se špatným koncem Wreck on the Highway pochází ze stejného roku jako Cadillac Ranch. Text písně popisuje př́běh muže, který je svěd-

3 Junior Johnson (narozen 1931) je legendární jezdec závodu NASCAR, který mezi lety 1955-1966 vyhrál 50 závodů. kem automobilové nehody, když se za deštivé noci vrací domů z práce: „Byla tam krev a kolem všude sklo. A nebyl tam nikdo, jenom já. Déšt prudce padal, tak těžký a studený. Viděl jsem mladého muže na okraji silnice, naříkal: ,Pane, můžete mi pomoci?‘. “ Hrozivý obraz se muži neustále vracel, pomýšlel na přítelkyni mladého muže a na policistu, který ji přijde ohlásit jeho smrt, stejně tak se nemohl vyhnout myšlenkám ohledně své vlastní smrtelnosti.

\section{Radost z jízdy a rychlosti}

Jedním z výrazných témat, které se v textech písní opakovaně objevuje, je opěvování rychlosti automobilů. At̉ už šlo o pouhý popis radosti z cesty automobilem a rychlé jízdy, její vyjádření v amatérském až profesionálním závodění či přenesenou prezentaci vlastního mužství, jehož prostřednictvím se muž snažil získat pozornost dívky/dívek. V písních se objevovalo vychvalování úžasných vzhledových i technických parametrů, které daný vůz měl. Samotná „rychlost“ pak s sebou přináší i varování, at už v podobě faktického zvýšeného rizika nehody či v metaforickém porovnání zrychleného způsobu života, v němž člověk ztrácí sám sebe.

Tak např́klad nejslavnější skladba amerického zpěváka Charlieho Ryana (1915-2008) Hot Rod ${ }^{4}$ Lincoln vypráví o chlapci a jeho neskonale rychlém automobilu. V písni je Hot Rod Lincoln popisován jako „nadupaný“ model s osmi válci, se schopností dosáhnout nejvyšší možné rychlosti, který není možné zastavit. Hlavní protagonista se neubránil jeho vábení a přestal vnímat veškeré zábrany a překážky, které by mohly zabránit v jeho „letu“. Nakonec ho v rychlé jízdě zastaví a následně zatknou policisté. „Zatkli mě a dali do vězení. A já zavolal tátovi, aby za mě zaplatil kauci. A on řekl: ,Synu ty mě dovedeš k pití, pokud nepřestaneš jezdit s tímhle Hot Rod Lincolnem.“” Tato píseň byla nahrána roku 1955 v reakci na skladbu Hot Rod Race napsanou Georgem Wilsonem pro Arkie Shibleyho \& Mountain Dew Boys, která byla hitem roku 1951. V jejím textu se hovoří o závodě mezi vozy Mercury a Ford v kalifornském San Pedru. První verze skladby z roku 1950 se stala základem série písní na téma „Hot Rod“, jež se objevovaly s cílem zopakovat prvotní úspěch z 50. a 60. let.

Motiv pouličních závodů přináší píseň Little Deuce Coupe z roku 1963 od slavné americké skupiny Beach Boys (obr. 4). Tyto závody byly populární zejména v 60. letech 20. století v jižní Kalifornii. Automobilem v názvu písně pak byl model Fordu z roku 1932 (deuce označuje „dvojku“ v letopočtu jeho vzniku), který disponoval velkým V8 motorem. Podobně jako v již výše zmiňované písni Chucka Berryho You Can’t Catch

4 Zejména ve Spojených státech amerických populární typ automobilu „Hot Rod“ označoval v průběhu 30. a 40. let minulého století automobily, kterým byl různými úpravami motoru zvyšován výkon tak, aby mohly dosáhnout co největší rychlost na rovných tratích. Původ tohoto názvu není zcela jasný, je možné, že vychází z vysokého výkonu motoru a ze změny zdvihu klikového hřídele, mohl ale také vzniknout zkrácením názvu „hot roadster“, tedy typu automobilu roadster, který byl upravován k vyšší rychlosti. 


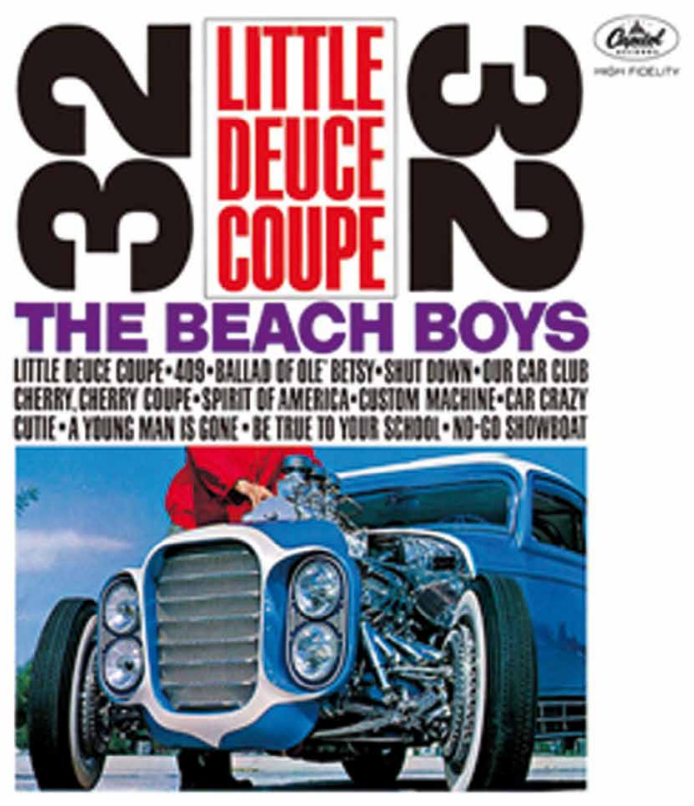

Obr. 4. Beach Boys a jejich Little Deuce Coupe. Pramen: http://en.wikipedia. org/wiki/File:LittleDeuceCover.jpg

Me je rychlost automobilu přirovnávána k pocitu svobodného létání. Dokonalost vozu je pak zdůrazňována slovy: „Dobrá, nechci se vychloubat, ale mám ta nejrychlejší kola ve městě. Nikdo by se neměl ani pokoušet ke mně přibližovat, protože kdyby měla kř́idla, určitě by mohla létat. Je to moje ,Little Deuce Coupe, vy ani nevíte, co mám.“ Zajímavostí v textu písně je výraz „pink slip“, který označoval vlastnictví papírů daného automobilu. „Racing for Pinks“ tak znamenalo, že vítěz na konci závodu získal vozidlo svého protivníka. V písni Little Deuce Coupe se tedy ř́ká, že pokud nechcete věřit, že je automobil skutečně tak rychlý, jak vychloubač tvrdí, vsadí se s vámi o všechno, co máte. Tematicky podobné jsou i další písně od Beach Boys, které se objevily na stejném albu jako Little Deuce Coupe - např́klad Car Crazy Cutie, Cherry, Cherry Coupe či 409.

Z roku 1991 pochází píseň Black Sunshine od americké heavy metalové kapely White Zombie, která vypráví o automobilovém závodu s Fordem Mustangem, který má přezdívku „Black Sunshine“. Na realizaci písně spoluúčinkoval i zpěvák Iggy Pop (narozen 1947), který v jejím „intru“ pronáší větu: „Pevné sevření kol, jeho klouby zbledly touhou. Kola jeho Mustangu explodovala jako šnek na čtyřicáté páté. Skutečná smrt: 400 koní z maximálního výkonu za mrazivé noci. Taková je ,Black Sunshine،““

Americká alternativně rocková skupina Cake v roce 1996 vystoupila s písní The Distance, která vypráví o řidiči závodního automobilu, který touží za každou cenu vyhrát. Jak pouka-

5 Pro lepší porozumění uvádíme i původní znění anglického textu: „And if that aint enough to make you flip your lid. There's one more thing, I got the pink slip daddy." zuje i hudební videoklip k písni, význam textu může být metaforickým přiblížením $\mathrm{k}$ úsilí dosáhnout úspěchu v jakékoli lidské činnosti, která může hraničit až s nebezpečným workoholismem a posedlostí po vítězství, kvưli čemuž si člověk přestává uvědomovat, že trofej, pro kterou závodil, si již dávno odnesl někdo jiný: „Když dosáhne cíle, vlajka označí konec závodu. Fanoušci vstanou a odjíždí z města. Aréna je prázdná, až na jednoho muže. Stálé řídí a snaží se, aby jel co nejrychleji. Slunce zapadá a měsíc vychází. A už dávno někdo odešel s pohárem. Ale on stále řídí, snaží se a projíždí zatáčkami. A myslí na někoho, pro koho stále hoří. Chce zvítězit, chce dosáhnout rychlosti. "Stejně tak mu toto závodění se sebou samým narušuje i mezilidské vztahy, což je v této písni vyjádřeno nastíněním situace jeho přítelkyně, která je „úplně sama ve chvílích, kdy ho potrebuje“.

Prezentace rychlého automobilu v obrazu vlastního mužství se objevuje v písni z muzikálu Pomáda (1978) Grease Lightning (v českém překladu jako „Náš auták“). Scéna ze slavného muzikálu, jehož symbolem byly napomádované vlasy, cadillacy a rock and roll, zavádí posluchače do prostředí autodílny, ve které skupina dospívajících chlapců sní, že si vyrobí automobil s rychlostí kulového blesku, na který nalákají jakoukoli dívku, když budou chtít: „Jo náš auták ten bude mistr na dráze, já rŕkám, jo náš auták i v soše vzbudí extáze. Je tutovkou, at’ holky řvou ,ty jsi náš auták!' Jo náš auták ten bude mistr USA. Já ř́kám: jo náš auták pak do muzea pověsej. Benzinu kapka, je buchtolapka, zahoukám a každou mám. Holka jak sen, už nechce ven - veze ji auták.“

Určitou futuristickou vizi budoucnosti, ve které jsou mnohé modely automobilů pro svoji „nebezpečnost“ zakázány tzv. „motoristickým zákonem“, nastiňuje píseň kanadské rockové skupiny Rush Red Barchetta (1981). Píseň byla inspirována futuristickou povídkou Richard Fostera A Nice Morning Drive (česky „Krásná ranní projížd'ka“), která byla uveřejněna v magazínu Road \& Track v listopadu roku 1973. Text popisuje, jak si strýc vypravěče jeden $z$ těchto ilegálních vozů, tajně skrytý ve stodole venkovské farmy, ponechal. Oním vozem byla červená sportovní barchetta, jež byla uchovaná ve stejně dokonalém stavu jako před padesáti lety. Každou neděli se pak vypravěč tajně vydával na farmu, aby se projel starým automobilem po okolí. Během jedné takové projížd'ky se setkal s velkým lesklým vzdušným automobilem („alloy air car“ - což by mohlo označovat policii), které jej začalo pronásledovat. Brzy se k němu přidalo ještě další podobné auto a společně jej pronásledovali, a to až do té doby, než se mu podařilo přejet přes most, který byl př́liš úzký pro mohutné vzdušné automobily. Píseň končí, když se vypravěči podaří bezpečně vrátit na farmu: „Dostal jsem zoufalý plán, díky úzkému mostu, uvěznil jsem obry na druhém břehu. Rychle jsem jel zpátky na farmu, snít se svým strýcem v bezpečí u krbu.“

V opozici k rychlým „hot rod“ stály takzvané „lowridery“. Píseň Low Rider složila skupina War a poprvé se objevila na jejich albu z roku 1975 Why Can't We Be Friends?. V této písni pojmenování „lowrider“ neoznačuje pouze druh automobilu s nízkým podvozkem, ale rovněž určitý typ subkultury majitelů těchto automobilů. Její podstatu vyjadřuje samotný text 
písně: „Low Rider řídí trochu pomaleji. Low Rider je skutečný chodec. Low Rider zná každou ulici yeah! Low Rider jediný to splňuje yeah! Low Rider nepoužívejte ted žádný plyn. Low Rider nejezděte př́liš rychle." Vedle toho se zde ale objevovaly verše jako „udělej si malý výlet“ či „Low Rider je o něco vyššsi“, které byly mnohými posluchači interpretovány jako zážitky z požití drog. Bubeník skupiny Harold Brown však tuto asociaci popíral s tím, že tyto interpretace jsou uměle vytvořené a poukazoval na to, že většina lowriderů pracuje jako automechanici, takže si nemohou vydělat dostatek peněz na drogy a veškeré finance vkládají do svých automobilů. To, že je „Low Rider o něco vyšši “ pak má vyjadřovat hrdost majitele na svůj automobil a způsob, jakým si řidič vychutnává jízdu. Původ tohoto druhu automobilu je u mexických přistěhovalců nazývaných „Chicanos“ na jihozápadě USA, mezi nimiž se objevila v průběhu 30. let touha vlastnit automobil, se kterým by si vychutnali pomalou jízdu po silnicích. Na základě toho se pak později vytvořilo motto všech lowriderů: „low and slow“ (španělsky „bajito y suavecito“). Zpočátku se efektu snižování dosahovalo vkládáním pytlů s pískem do kufru, později si řidiči zkracovali tlumiče, či dokonce řezali sloupky, snižovali střechy. Na tyto a jiné podobné „úpravy“ pak v roce 1958 reagoval zákon, který ř́kal, že se na silnici nesmí objevit žádný vůz, který by měl jakoukoli část nižší než je límec jeho ráfků. V roce 1959 se ale díky automechanikovi Ronu Aguirremovi podařilo zákon obejít. Pomocí systému hydraulických čerpadel, pump a ventilů se mohla výška vozidla upravit pouhým přepnutím ovladače. Jedním z prvních automobilů, který se hodil pro instalaci hydraulického podvozku, byl Chevrolet Impala z roku 1958, který dodnes patří mezi nejoblíbenější vozidla pro lowridery.

Z lowridingu se postupem času vytvořil určitý životní styl a kolem roku 1990 začal být jedním z elementů mladé rapové a hip-hopové scény západního pobřeží. „Lowriderové“ vozy se stávají důležitou součástí hudebních videoklipů, jejichž schéma je víceméně podobné. Za všechny uved’me například píseň Still D.R.E. v podání zpěváka Dr. Dre z roku $1999 \mathrm{~s}$ přehlídkou krásných aut a spoře oděných dívek v jejich interiérech či v roce 2001 americkou hip-hopovou kapelou Cypress Hill natočený videoklip s názvem Lowrider, v němž se členové skupiny bezstarostně projiždějí za slunečného počasí v nablýskaném fialovém voze po kalifornských silnicích.

\section{Auto a ženy}

Auto, ženy a sex je spojení, které se promítalo do řady textů. Metaforické přirovnávání automobilu k sexuálnímu styku či k ženskému tělu se začalo objevovat od přelomu 19. a 20. století.

Již z roku 1905 tak například pochází populární píseň In My Merry Oldsmobile (obr. 5) v podání jednoho $\mathrm{z}$ nejúspěšnějších zpěváků první dekády 20. století Billy Murraye (18771954), ke které složil hudbu Gus Edwards a slova napsal Vincent P. Bryan. Obálka původní gramofonové desky zobrazovala muže a ženu na projížd'ce idylickou venkovskou krajinou. $\mathrm{V}$ textu je patrné propojení milostného románku dvou

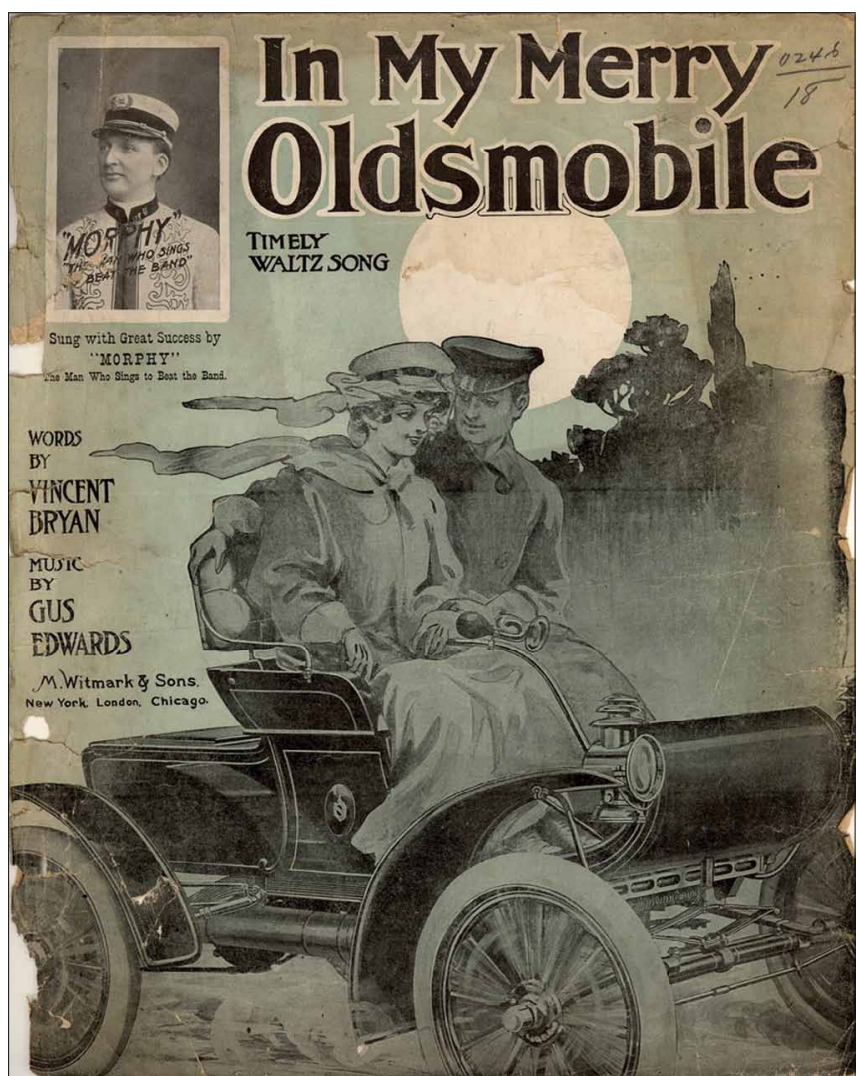

Obr. 5. Populární píseň In My Merry Oldsmobile z roku 1905. Pramen: http:// en.wikipedia.org/wiki/File:In_My_Merry_Oldsmobile_a2701-1-72dpi.jpeg

lidí s tématem automobilu. Píseň vypráví o Johnnie Steeleovi, jeho Oldsmobilu a milované dívce. Je zde možné nalézt řadu dvojznačných narážek na vztah této trojice: „Milují ,jiskření ve starém tmavém parku, je to jakoby společně létali. Ona ř́ká, že ví, jak motor funguje, ,jiskra je velmi silná. Každý den se ,ruku v ruce milují za zvuku motoru, brzy budou mít líbánky.“ Sbor pak v refrénu zpívá: „Můžete jet se mnou tak daleko, kam budete chtít, v mém veselém Oldsmobilu!“ General Motors používal píseň s pozměněnými verši několik desetiletí v reklamních spotech na Oldsmobile ${ }^{6}$.

V roce 1965 přichází slavná britská skupina Beatles s písní Drive My Car, která byla součástí alba Rubber Soul. V textu písně se seznamujeme s dívkou, která sní o tom, že se jednou stane slavnou filmovou herečkou. Se svým snem se svěří muži, který jí podle jejího názoru může pomoci vysněného cíle dosáhnout: „Zlato, můžeš řídit mé auto, ano, já budu hvězda. Zlato, můžeš řídit mé auto a možná tě budu milovat." Právě výraz „ř́idit auto“ může být v této souvislosti vnímán jako eufemismus pro sexuální styk. Na její lákavou nabídku muž odpovídá: „Pověděl jsem té dívce, že bych mohl začít

6 U zrodu značky Oldsmobilu stál Ransom E. Olds, který v roce 1897 založil firmu Olds Motor Vehicle, jež byla od roku 1908 součástí General Motors. Značka Oldsmobile se brzy stala synonymem vozů pro stř̌ední třídu a střední věk - dražší než Chevrolet a Pontiac, avšak levnější než Buick a Cadillac. 


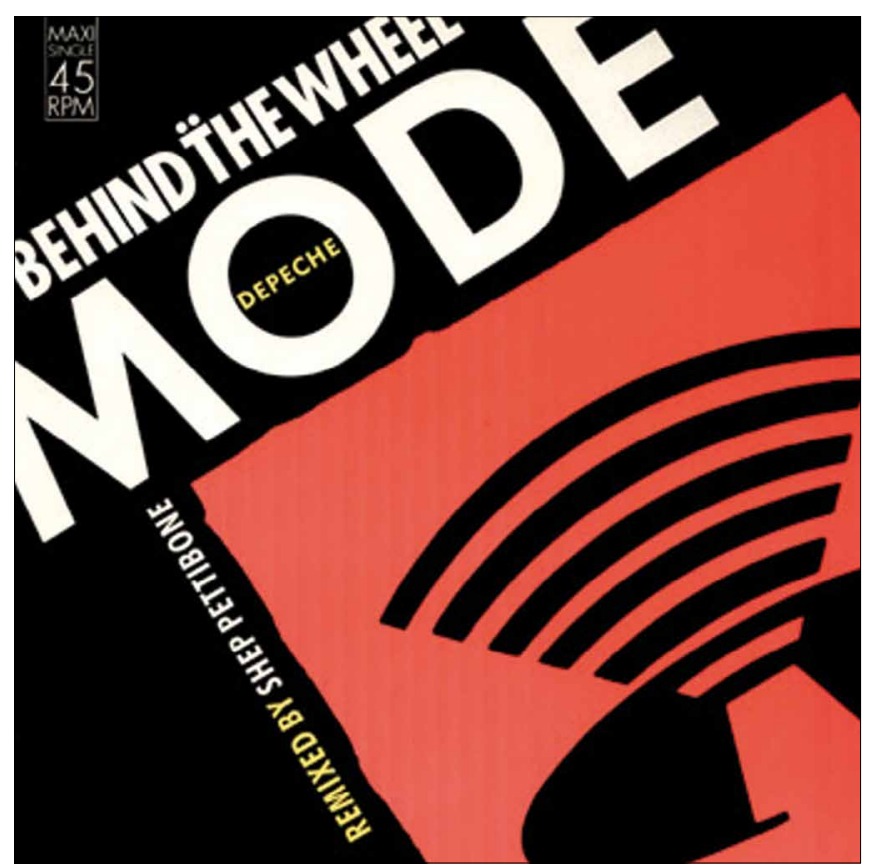

Obr. 6. Obal k singlu Behind the Wheel od Depeche Mode. Pramen: http:// en.wikipedia.org/wiki/File:DepecheModeBehindTheWheel.jpg

hned.“ Dívka se mu ale svěřuje: „Nemám žádné auto a to mi láme srdce. Ale našla jsem zatím alespoň řidiče.“

Jedním $\mathrm{z}$ témat, která se v písních dále objevují, je zodpovědný, dominantní muž, který na chvíli propůjčí svůj automobil ženě. $\mathrm{V}$ textech jsou vyjádřeny obavy $\mathrm{z}$ ženiny nezkušenosti, nezodpovědnosti, možná i výsměch její naivitě, se kterou k řízení přistupuje.

O tom, co se stane, když se automobil dostane do rukou ženy, vypráví například píseň Mustang Sally. Tuto píseň napsal a poprvé nahrál americký hudebník Mack Rice (narozen 1933) v roce 1965. Rice text k písni napadl, když se mu zpěvačka Della Reese ve vtipu svěřila, že by chtěla vlastnit Ford Mustang. Rice nejprve píseň pojmenoval jako „Mustang Mama“, ale na návrh Arethy Franklin název následně změnil na „Mustang Sally“. Více než Riceův originál je ale známějšı coververze od amerického soulového zpěváka Wilsona Picketta (1941-2006). Píseň vypráví o nespoutané dívce, která cestuje po městě ve svém zbrusu novém Mustangu. V refrénu písně je dívka varována, aby svou jízdu zpomalila, přičemž těmito slovy mohlo být obecně míněno, aby zpomalila svůj život, nebyla tak divoká, nezodpovědná a nerozumná a začala na svět pohlížet realističtěji: „Mustang Sally, myslím, že budeš muset svůj Mustang zpomalit. Uháníš jím ted’ přes celé město. Oh! Zřejmě budu muset postavit tvé ploché nohy na zem.“

Toto téma, avšak v opačné rovině, se objevuje u skupiny Depeche Mode, která ve své písni z roku 1987 s názvem Behind The Wheel (obr. 6) zpívá o muži, který se na jeden večer chce ocitnout ve vyloženě submisivní roli spolucestujícího a vyzývá svou dívku, aby se chopila vedoucí/řídící role a to nejen ve smyslu ř́zení automobilu, ale i v jejich vztahu samotném: „Má holčičko, jed’ kamkoliv, dělej co chceš, je mi to jedno.
Dnešní noc jsem v rukou osudu, sám se nyní držím nad zemí. Ó má holčičko, občas mám pocit, že bych raději neměl být za volantem. Přijed', ovládej mne, sleduj můj pohyb, dělám vše možné.“

Proměnu genderových rolí za volantem zmiňuje rovněž americká skupina Eels v písni Woman Driving, Man Sleeping $\mathrm{z}$ roku 2011. Ústřední pár v textu písně se vydává začít nový život. Zatímco aktivní žena za volantem směřuje $\mathrm{k}$ řešení jejich problémů, muž ve spánku sní o velkém rodinném domě: „Žena řídí, muž spí. Míjejí všechna ostatní auta. Pátrají v temnotě, ale nikdy se neohlížejí zpátky. Malá kovová krabice pod hvězdami.“

Trochu jiný motiv se objevuje v písni skupiny Beach Boys Fun Fun Fun z roku 1964. V textu písně se zpívá o rebelské dívce, která si pod záminkou, že musí jít studovat do knihovny, půjčí od svého otce automobil (konkrétně oblíbený model T-Bird, který byl v tehdejší americké společnosti symbolem mládí, bohatství a úspěchu). Brzy ale podlehne svodům jeho krásy, zapomene na povinnosti, začne se bavit a užívat si jízdu: „Ostatní holky jí závidějí, protože chodí, vypadá a řídí skvěle. Jede, jakoby to byl závod Indy 500 a vypadá jako vozataj na římských závodech. Spousta kluků se ji pokouší dohnat, ale vede je za sebou jak hejno hus."Když otec dívky zjistí, co udělala, vezme si T-Bird zpátky. Mohlo by se zdát, že veškerá zábava skončila, ale dívka se otci pomstila, když utekla s mužem, který se do ní zamiloval poté, co viděl její rychlou jízdu. Tento př́běh vychází z reálné události, která členy skupiny Beach Boys k napsání písně inspirovala. Hlavní hrdinkou byla Shirley Johnson England, která v té době pracovala na poloviční úvazek jako sekretářka v rádiu KNAK. Generální ředitel této rozhlasové stanice Bill Hesterman byl blízkým přítelem s Murrayem Wilsonem, otcem tři členů skupiny Beach Boys - Briana Wilsona, Carla a Denise. Beach Boys měli v rádiu KNAK několik rozhovorů a zde se také setkali se Shirley, která si občas od svého otce půjčovala automobil. Jednou večer řekla svému otci, že jede do knihovny, ale namísto toho se jela bavit s prráteli (Robinson 2005).

Píseň zpěváka Prince (celým jménem Prince Rogers Nelson, narozen 1958) Little Red Corvette podobně jako Mustang Sally přináší motiv potřeby zpomalení a usměrnění ženské energie. Dívka lehčích mravů, která řídí červený automobil Corvette, je mužem nabádána, aby si uvědomila, že se musí mírnit ve svém způsobu života, aby se z ní nestala pouhá dívka na jednu noc, za kterou je většinou mužů považována: „Malá červená Corvette, miláčku jsi př́liš rychlá, malá červená Corvette, potřebuješ najít lásku, která bude trvalá...“ $\mathrm{V}$ písni se objevuje několik odkazů na sexualitu, které byly uvedeny do symbolické roviny, aby nepůsobily př́liš pobuřlivě. Například věta: „měla kapsu plnou koní, trojských koní, někteří $\mathrm{z}$ nich je používají“ odkazuje na prezervativy značky Trojan. „Žokeje“ ve větě „bylo mi trochu nevolno, když jsem viděl fotografie všech těch žokejů, kteři tu byli přede mnou“ představují muže, kteří předtím spali s onou dívkou.

$\mathrm{V}$ některých případech mizí rozdíly $\mathrm{v}$ citovém poutu muže $\mathrm{k}$ ženě a emocím vyjadřovaným automobilem. Takovým příkladem je píseň Highway Star (1971) jedné z nejslavnějších 
speedmetalových skladeb skupiny Deep Purple. Píseň vypráví př́běh o muži a jeho lásce $\mathrm{k}$ rychlým a silným autům, přičemž, jak je patrné $\mathrm{z}$ textu, láska $\mathrm{k}$ automobilu, kterou přirovnává $\mathrm{k}$ bouřlivému hurikánu, splývá s láskou $\mathrm{k}$ dívce. $\mathrm{V}$ první sloce se zpívá: „Nikdo mi nevezme auto, hodlám s ním závodit. Nikdo nepřekoná moji káru, překoná rychlost zvuku. Oh, je to vražedný stroj, má všechno, jako třeba hnací sílu velkých silných pneumatik a vůbec všechno." V porovnání se ženou: „Nikdo mi nevezme mou dívku, chci ji mít navždy. Nikdo nebude mít mou dívku, bude mi na blízku v každé zatáčce. Oh, je vražedným strojem, má všechno. Jako třeba pohybující se ústa, kontrolu nad tělem a vưbec všechno." V poslední sloce pak autor opěvuje svoji mysl, která předcházející dvě modly spojuje a zasazuje do roviny racionality a sebeovládání a také přispívá k posílení sebevědomí a prohlášení, že ,jsem hvězda dálnic".

Do extrému je uveden vztah muže a automobilu v textu písně Rogera Taylora (narozen 1949), bubeníka britské rockové skupiny Queen, který v roce 1975 napsal píseň I’am in Love with My Car. Tato píseň vypráví o muži, který miluje svůj nablýskaný automobil, stroj snů, mnohem víc než jakoukoli ženu: „Své holce jsem řekl, že zapomenout na ni musím. Radši si nový karburátor koupím. Tak mi zdrhla se slovy: ,To je konec'. Ale auta neodmlouvají. Přátelé na čtyřech kolech.“

\section{Nebezpečnost automobilu}

Automobil však není jen snem o rychlosti, ženách, benzinu, ale je s ním neodmyslitelně spjat i aspekt nebezpečnosti. Otázky pomíjivosti života, zbytečnost umírání či frustrace nemožnosti zabránit děsivé nehodě, která může zasáhnout každého z nás, se nutně odrážejí i v textech populárních písní. Onu nepřímo vyjádřenou hrozbu smrtelného nebezpečí v sobě nese píseň Diesel Smoke, Dangerous Curves od amerického country zpěváka Reda Simpsona (narozen 1934) z roku 1967. Simpson měl několik písni, které spadaly do tzv. žánru „truck driving country“, jejichž texty byly věnovány životu řidičů kamionů. A právě v této písni se vypravěč svěřuje, jak prohýŕil minulou noc: „Byl jsem včera na pivu s klukama, bolí mě hlava, mám krvavé oči. Skončil jsem s malou hezkou holkou, jejíž jméno si už nepamatuji...“ A ted’ se musí potýkat s následky a vypravit se na cestu horskými silnicemi: „Pokud chci včas doručit toto zboží, musím sebou hnout, protože už jedu pozdě. Tyhle stoupající hory jsou ohromné a prudké. Musím zůstat vzhůru, nesmím usnout." Přesto se ale únavě neubrání a musí alespoň na chvíli za kouře motoru a v nebezpečných zatáčkách oči zavřít. Jak příběh skončil se už ale $\mathrm{z}$ písně nedozvídáme.

Skupina Beatles se v písni z roku 1967 A Day in the Life, jež má zdůraznit vzácnost každého dne a pomíjivost života, zmiňuje o zprávě $z$ novin, která informovala o úspěšném muži, který zemřel v důsledku automobilové nehody: „Dnes jsem četl v novinách o štastném a úspěšném muži, který to někam dotáhl. A ačkoliv ta zpráva byla smutná, tak jsem se prostě musel smát. Viděl jsem jeho fotografii, přišel o život $v$ autě. Nevšiml si, že se na semaforech změnila barva. Dav lidí jen

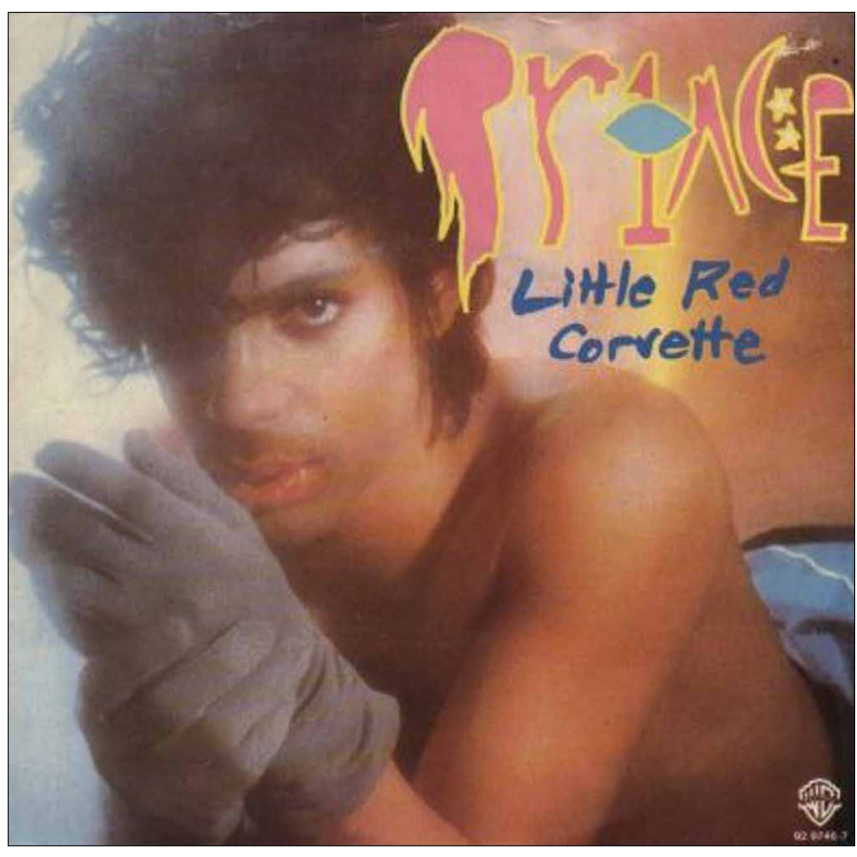

Obr. 7. Obal k singlu Little Red Corvette od Prince. Pramen: http://en.wikipedia.org/wiki/File:Prince_LRC.jpg

stál a zíral. Zdálo se, že jeho tvář už někdy předtím viděli, ale nikdo si nebyl zcela jistý. Mohl být ze Sněmovny Lordů.“

Britský autor alternativní rockové hudby David Bowie (narozen 1947) v písni z roku 1977 Always Crashing in the Same Car vyjadřuje frustraci $z$ neschopnosti se poučit a opakovaného dělání stejných chyb. Vypravěč popisuje, jak za vysoké rychlosti neustále krouží automobilem kolem hotelové garáže, obezřetně kontroluje nebezpečí, ale přesto vždycky nevyhnutelně havaruje, když se na něj podívá dívka jménem Jasmine: „Ty kilometry a červená světla. Vždy jsem se podíval vlevo a vpravo. Oh, ale vždycky havaruji ve stejném autě. “

Jedna $\mathrm{z}$ největších ikon současné americké rockové scény Meat Loaf (vlastním jménem Marvin Lee Aday, narozen 1947) v roce 1977 přišel s písní Bat Out of Hell, kterou pro něj, podobně jako jiné písně, složil pianista Jim Steinman (narozen 1947), který chtěl přijít s nejextrémnější písní o nehodě na dálnici všech dob (Steinman 1999). Píseň měla v sobě určitý nádech vzrušení, které se objevovalo při představě nebezpečné katastrofy. Motiv zhoubné rychlosti je vyjádřen slovy: „Jel jsem rychleji, než jakýkoli jiný chlapec... byl jsem tak zaujatý, že jsem si nevšiml zatáčky, dokud nebylo př́liš pozdě. “V poslední sloce pak vypravěč zpívá o svém umírání: „A tak umírám, na dně jámy za žhnoucího slunce. Rozervaný, zkroucený u hořícího kola... a poslední věc, kterou vidím je mé srdce. Stále bijící, vypadlé z mého těla a letící pryč jako netopýr z pekla." Píseň Fuel od americké trash-metalové kapely Metallica z roku 1996 vyjadřuje fakt, že lidé touží řídit svoje životy stejně rychle jako automobily a poté, co se dostanou do extáze z rychlosti rovnající se drogové závislosti („palivo se čerpá, drsně hoří, v pohodě a svěží..."), začínají zapomínat na jakýkoli pud sebezáchovy: „Vem to za roh a vysekáme se, čelní světla, titulní stránky, další feták, co žil příliš rychle.“ 


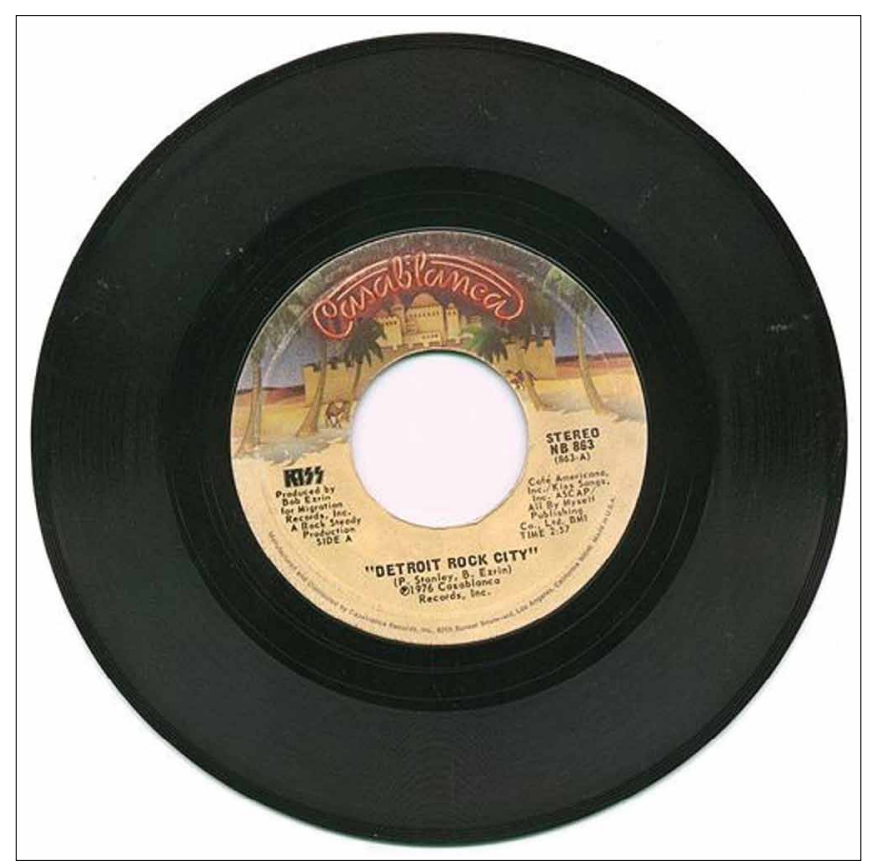

Obr. 8. Deska Detroit Rock City od skupiny Kiss. Pramen: http://en.wikipedia. org/wiki/File:Detroit_Rock_City.jpg

Někdy byly písně o automobilových nehodách inspirovány skutečnými událostmi, jako např́klad z roku 1994 pocházející Daddy's Speeding britské alternativní skupiny Suede, která byla určitou elegií na smrt herce Jamese Deana a vůbec výpovědí o hrozbě automobilových nehod v současné společnosti a zbytečnosti umírání mladých lidí: „A zármutek naruší tichý den, vezme si mladého chlapce pryč. Nabourají v autech a nechají nás tady. Se sny o benzinu sušíme si slzy. Zelená pole a smrtící stroje vysoko v nebi.“

Téma automobilu a smrti se objevila i v písni americké rockové skupiny Kiss Detroit Rock City z roku 1976 (obr. 8). Vypráví skutečný př́iběh o mladém fanouškovi, který zemřel v automobilu, když jel na koncert této skupiny. Fanoušek, který se na koncert chystal, si uvědomil, že je nejvyšší čas a rychle se vydal na cestu. Jel tou nejvyšší možnou rychlostí, když „najednou zde byl přede mnou nákladák, jeho světla mě oslnila. Oh, můj bože, není cesty. Dostal jsem záchvat smíchu, protože jsem věděl, že zemřu“.

Americký rapper Eminem (vlastním jménem Marshall Bruce Mathers III, narozen 1972) v písni Stan z roku 2002 vypráví fiktivní příběh muže, který tvrdí, že je Eminemův největší fanoušek. Muž zpěvákovi v průběhu děje písně píše dopisy, ve kterých se jeho posedlost stupňuje, stejně jako vztek, když mu Eminem neodpovídá. Nakonec mu zasílá zvukový záznam z okamžiku, kdy plánuje se svou těhotnou přítelkyní svázanou v kufru vjet autem do jezera: „Tohle je kazeta, kterou ti posílám. Doufám, že to slyšíš. Právě jsem v autě. Jedu devadesátkou po dálnici. Hej Slime, vypil jsem dvoudecku vodky, necháš mě řídit?... Hej Slime, to je řev mý holky v kufru. Ale nepodřízl jsem jí krk, jenom jsem ji svázal, koukni, nejsem jako ty. Protože, když se dusí, bude víc trpět a pak taky umře. Tak jdem na to, už jsem skoro na mostě." V závěru pís- ně Eminem fanouškovi konečně odpovídá, $v$ naději, že není pozdě. Pak se ale kruh uzavírá a zpěvák si uvědomí, že před pár týdny viděl ve zprávách, jak nějaký opilý muž sjel autem z mostu: „A v kufru měl holku, která čekala jeho dítě. A v autě našli kazetu, ale neřekli, komu patřila. Zamysli se nad tím. Jmenoval se... byl jsi to ty. Sakra!“

$\mathrm{V}$ některých př́padech může být automobil považován za bezpečnější zázemí, než realita mimo něj. Z roku 1979 pochází píseň britského zpěváka Garyho Numana (narozen 1958) Cars, která poukazuje na to, jakým způsobem lidé využívají moderních technologií k izolaci od kontaktu s ostatními lidmi: „Tady v autě, cítím se nejbezpečněji. Mohu zamknout všechny své dveře. Je to jediný způsob, jak žít. V autech.“'Text k této písni vznikl na základě incidentu, který zpěvák zažil, když se jednou ocitl v zácpě v Londýně. Najednou k jeho autu přistoupila skupina lidí, kteří ho chtěli zmlátit a vytáhnout z auta. Zpěvákovi se podařilo zamknout dveře, vjet na chodník a dostat se do bezpečí. Tato píseň tedy zdůrazňuje, jak bezpečně se může člověk cítit ve svém automobilu. Jak Numan zdůraznil v rozhovoru z roku 2001: „Když jste uvnitř, změní se celá mentalita, je to jako vaše soukromé království se čtyřmi koly“ (viz http://www.kaos2000.net/interviews/garynuman/).

\section{Písně žen o autech}

Za samostatnou kapitolu lze považovat prezentaci tématu automobilu ženami-zpěvačkami. Leckomu se v této souvislosti vybaví legendární píseň Mercedes Benz americké bluesové a rockové zpěvačky Janis Joplin (1943-1970), kterou nahrála jen několik dnů před svou smrtí. V této písni Joplin prosí Boha o vyjádření důkazu lásky a spravedlnosti: „Bože, koupíš mi Mercedes Benz? Všichni mí přátelé mají Porsche, potřebuji si to vynahradit. Celý život jsem tvrdě pracovala, nikdo z nich mi nepomohl. Tak bože, koupíš mi Mercedes Benz?“ Píseň byla také několikrát použita $\mathrm{v}$ reklamní kampani Mercedes-Benz (1995, 2007, 2011), sama Joplin však nikdy Mercedes nevlastnila, ale ironicky $\mathrm{k}$ textu písně je $\mathrm{s}$ její osobou spjato tzv. psychedelické Porsche (obr. 9) (viz níže).

Pokud se podíváme na tendence dnešní pop music, je možné velice často pozorovat porovnávající paralelu, kdy je nádherný automobil přirovnáván ke krásnému ženskému tělu. Zpěvačky pak otevřeně skrze pozvání mužům, aby vstoupili do jejich automobilu, nabízejí i svou vlastní sexuální dostupnost. V současné době mediálně a komerčně velice úspěšná zpěvačka Rihanna (vlastním jménem Robyn Rihanna Fenty, narozena 1988) v písni z roku 2007 Shut up and Drive (nutno ale podotknout, že zpěvačka si píseň nenapsala sama a pod jejím autorstvím je podepsáno šest mužů) vyjadřuje touhu nalézt kvalifikovaného řidiče, který převezme kontrolu nad jejím novým autem, stejně jako jí samotnou. „Můj motor je připravený vybuchnout, vybuchnout, vybuchnout. Tak mě nastartuj a sleduj, jak jedu, jedu, jedu... Dostanu tě kamkoli budeš chtít, jestli víš, jak to myslím. Mám auták, který je lepší, než limuzína. Zvládneš ty křivky? Dokážeš rozsvítit všechna světla? Jestli jo, chlapečku, tak můžeme jezdit celou noc.“ Ero- 


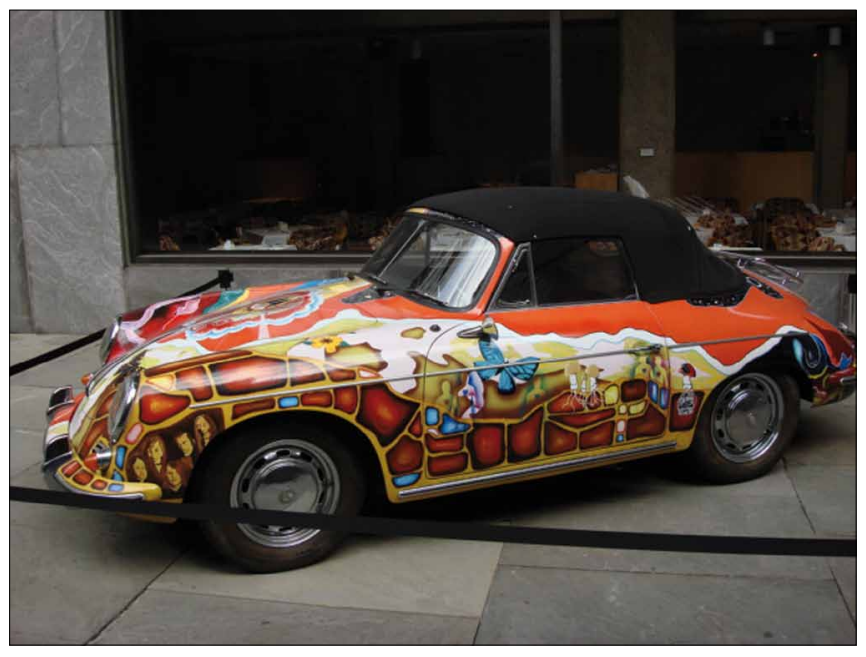

Obr. 9. Psychidelické Porsche Janis Joplin. Pramen: http://en.wikipedia.org/ wiki/File:Janis_Joplin\%27s_Porsche_356_convertible.jpg

tický podtext slov podtrhuje vizuální stránka videoklipu (obr. 15). Ten začíná scénou, ve které zpěvačka oblečená do svůdných úzkých kalhot a s botami na vysokých podpatcích vstupuje do autodílny, kde se spolu s podobně oděnými dívkami pouští do oprav automobilů, přičemž primárním principem je zviditelnit propojení ženských křivek s modely jednotlivých aut a vyvolat $v$ mužských posluchačích představu, že jejím řidičem se mohou stát právě oni.

Podobně i populární americká zpěvačka Madonna (vlastním jménem Madonna Louise Veronica Ciccone, narozena 1958) v písni z roku 2012 Superstar se svému mužskému idolu vyznává: „Jsem tvoje největší fanynka, je to tak. Beznadějně tebou okouzlená. Mưžeš mít klíče $\mathrm{k}$ mému autu, zahraji ti píseň na kytaru."

Americká zpěvačka s image nezávislé popové hvězdy Lana del Rey (vlastním jménem Elizabeth Grant, narozena 1986), jejíž umělecký pseudonym se skládá $\mathrm{z}$ kombinace jména hollywoodské herečky Lany Turner a automobilu Ford Del Rey, v písni Driving Cars with Boys (2012) zpívá o dívce, která celý svůj život strávila ježděním v autě s muži (obr. 10): „Jízdou kolem města, pitím v tom bílém šumu. Povídali jsme si o tom, kde budeme a kam půjdeme." Vypravěčka si uvědomuje pomíjivost a krátkodobost těchto jízd, ví, že všichni ti muži mají přítelkyně, ale stačí ji vědomí, že ona je tou, kterou chtějí v daný okamžik: „Narodila jsem se, abych umřela mladá. Opustila nádherné tělo, žila svůj život v běhu. Mám své peníze, Louis Vuittona, diamanty, a zbraně. Holky se chtějí jen bavit."

Automobil propojený s nabídkou k sexu najdeme i u skotsko-americké skupiny Garbage. Její zpěvačka Shirley Manson (narozena 1966) v písni z roku 1996 Driving Lessons láká muže na projíždku automobilem, jejímž prostřednictvím mu umožní splnění jeho snů: „Mohu z Vás udělat čestného muže, pokud chcete. Mohu z Vás udělat slušňáka, pokud mě chcete. Mohu zajít velmi daleko. Stačí si vzít auto."

V roce 1994 slavné švédské duo Roxette vydalo píseň s erotickým nádechem Sleeping in my Car. Text a hudbu složil

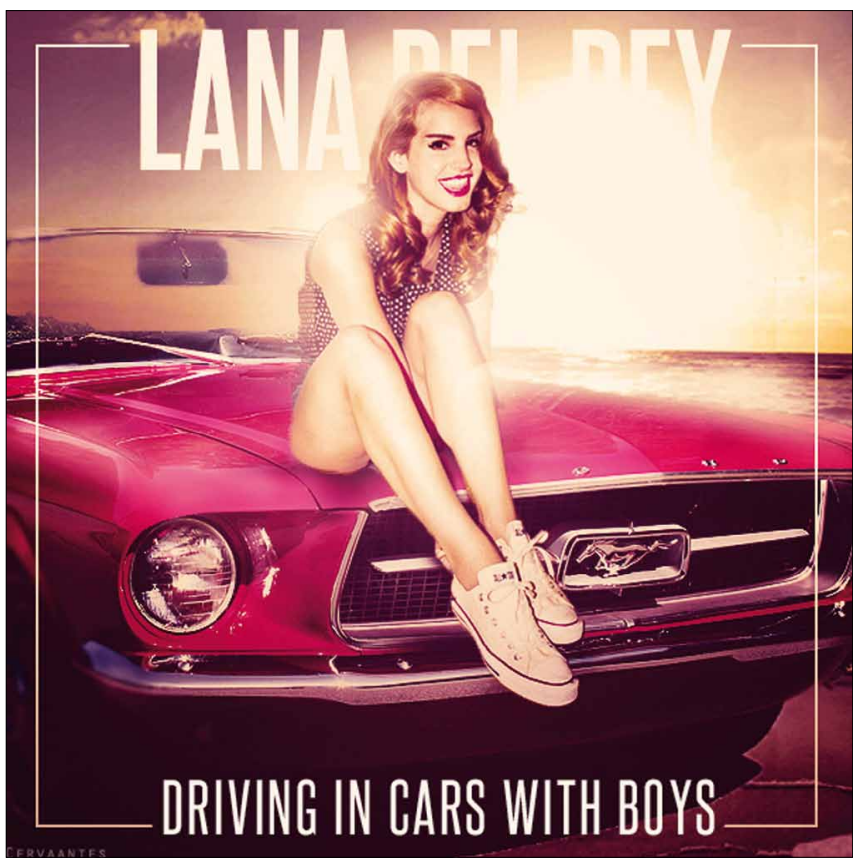

Obr. 10. Lana Del Rey - Driving in Cars With Boys. Pramen: http://www. flickr.com/photos/cervaantes08/6733897361/

mužský člen dua Per Gessler, nicméně píseň je v podání zpěvačky Marie Fredriksson, která v refrénu zpívá: „Budeme spát $\mathrm{v}$ mém autě, svléknu tě. Budeme spát $\mathrm{v}$ mém autě, budu se s tebou mazlit. Zůstaneme na zadních sedadlech mého auta a budeme se milovat."

Stejně tak v písní americké dívčí rockové skupiny The Donnas z roku 2002 Take Me to the Backseat je otevřeně vyjádřeno, že dívky nestojí o nějaké skryté hry a namlouvání a přejí si, aby je muž rovnou vzal na zadní sedadlo automobilu: „Nechci jít do obchodáku, nechci jít do kina. Myslím, že jsme už dělali všechno. Tak mě vezmi na zadní sedadlo."

Trochu jiné obsahové formáty nacházíme v písních zpěvaček, které komerci nepodléhají a své texty si většinou píší samy. Např́iklad americká písničkářka Tracy Chapman (narozena 1964) v písni z roku 1988 Fast Car vypráví příběh dívky, která vyrůstá s otcem alkoholikem, jehož její matka opustila. Sama ale $\mathrm{v}$ péči o otce nenachází naplnění a přemlouvá prrítele, aby spolu odjeli z města a začali nanovo. Automobil se stává nadějí a prostředkem, ve kterém vidí možnost, jak uniknout ze svízelné situace, ale zároveň i únikem od minulosti a zodpovědnosti: „Vzpomínám si, jak jsme jeli tvým autem tak rychle, až se mi zdálo, že jsem opilá. Světla města zářila před námi a tobě se líbilo, jak jsi mě objímal kolem ramen, a připadalo mi, že konečně někam patř́m, a měla jsem pocit, že mohu někým být." Jenže vše se uzavírá v patetickém kruhu. Ženě se podaří v novém životě sice nalézt práci, díky které může oba uživit, ale její partner čím dál tím častěji vysedává v barech a stává se kopií jejího otce: „Vždycky jsem doufala v to lepší, myslela jsem, že bychom to společně mohli najít. Ted' už nemám žádné plány a nechci nikam jet. Tak si vezmi své rychlé auto a jed' dál.“

Automobil se stává prostředníkem k úniku od nežádoucí situ- 
ace také pro kanadsko-americkou zpěvačku Alanis Morisette (narozena 1974) v písni Giggling Again for No Reason (2007). Žena v textu písně už nemůže vydržet neustálý tlak lidí kolem sebe, kteří od ní neustále něco chtějí, a tak se bez jakéhokoli vysvětlování vydává automobilem na dálnici, kde otevírá okno a konečně pocituje potřebnou svobodu a nezávislost: „Oh, ten pocit svobody. Nic krom silnice mi ji nemohlo dát. Ta svoboda pocitovaná skrze vítr šlehající na tvár. A já jsem se smála bez důvodu."

Americká zpěvačka a písničkářka Tori Amos (vlastním jménem Myra Ellen Amos, narozena 1963) svoje stěžejní téma mezilidských vztahů přenesla i na motiv automobilu v písni Cars and Guitars (2008). Vypravěčka zde partnerovo zacházení s ní přirovnává ke způsobu, jakým ovládá automobil: „Kdybych se dusila, chlapče, můžeš mě znova nastartovat. Vyměnit mi dráty, ty vís. Tahle převodovka může zbavit lesku mé ráfky. Zatraceně, jestli to uděláš. Zatraceně, jestli ne. Přísahám, že je pozdě chlapče. Dokonce jsem zahnula své tělo, aby se přizpůsobilo Tvému luku.“

Motiv partnerského vztahu vyjádřeného prostřednictvím automobilu se objevuje i u kanadské zpěvačky Joni Mitchell (vlastním jménem Roberta Joan Anderson, narozena 1943) v písni Car on a Hill z roku 1974. V ní popisuje, jak s obavou a úzkostí čeká, jestli se k ní vrátí její milý, či se bude muset smírit s verdiktem, že byla jen jeho jednorázovou aférkou: „Seděla jsem a čekala, jestli se můj drahý objeví. Poslouchala jsem rádio a sirény. Ř́kal, že bude pryč jen tři hodiny. Vyhlížím jeho auto na kopci. Snadno se spřátelí. Není jako já. Úzkostlivě očekávám jeho rozhodnutí.“

Americká zpěvačka Norah Jones (vlastním jménem Geetali Norah Jones Shankar, narozena 1979) v roce 2012 zpívá v písni Out on the Road o svém rozchodu. Samotný název písně je určitou metaforou $\mathrm{k}$ vyjádření pocitu potřeby odchodu, nezávislosti a nalezení sebe samé po rozpadu vztahu: „Asi tě budu muset milovat $\mathrm{z}$ dálky. Ach, je to $\mathrm{v}$ pořádku, protože všechno, co potřebuji je moje auto.“

Podobně melancholické vyznění má i píseň gruzínsko-britské bluesové a jazzové zpěvačky Katie Melua (narozena 1984) On the Road Again (2007), ve které vyjadřuje únavu nad veškerým soupeřením a spory ve vnějším světě, od kterých skrze cestování uniká, ačkoli nemá žádného společníka ani konkrétní místo, kam směřuje: „Jsem tak unavená z pláče, ale stejně jsem zas venku na cestě, jsem zase na cestě.“

\section{České texty o autech}

„Povídal mi docent Černý, že už Robert přestal psát / svoje celkem bezvadný texty o autácích. / Ale abych neměl strach, že zas bude nový psát, / skoro stejně úletný, asi o pankáčích.“ Uvedený text zpívá skupina Tři sestry v jedné ze svých prvotin $\mathrm{z}$ osmdesátých let minulého století. Texty s automobilovou tematikou se však v české hudební tvorbě začaly objevovat mnohem dříve, a to, podobně jako $\mathrm{v}$ zahraničí, již $\mathrm{v}$ době, kdy se $\mathrm{v}$ českých zemích začaly objevovat první automobily. Prvními českými písněmi o automobilech se v článku „Já mám automobil“ zabývá historik záznamu zvuku Gabriel
Gössel. Podle Gössela se pravděpodobně poprvé téma automobilů v podání českých umělců objevilo na gramodeskách již počátkem dvacátého století u prŕležitosti uvedení operet Autovíla z roku 1912 od německého skladatele Jeana Gilberta nebo Rozvedená paní z roku 1908 od vídeňského skladatele Leo Falla v pražské Vinohradské zpěvohře. Téma automobilu i jiných dopravních prostředků v tehdejších populárních písních a kupletech Gössel rozděluje do několika rovin. Jednalo se např́klad o ódy na správný typ automobilu, který zvyšoval společenskou prestiž jeho majitele (například píseň Jiřího Sedláčka z roku 1931 Na každého hledím spatra, kdo nejezdí vozem Tatra), trefná přirovnání ke značkám rychlých vozů („Tam se hoši s děvčátky líbaj v rytmu bugatky“) či dvojsmysly s erotickým podtextem („Máš-li nové gumy, nárazy to tlumí). Další významnou skupinu tvořily podle Gössela písně o pražských taxíkárích a jejich svérázných manýrách, jak je ilustrováno například textem: „Jede, kam chtěl o sto šest, šofér Lojza pět set šest. Ondy hejsek do autáku mého zdráhal se vám vlézt, že prý v takovém hnojníku nemůže se nechat vézt. Přec tam sedl a poručil ,jedte! - Já však povídám: ,Nejdřív musím, pane, vědět, kam pak ten hnůj odvézt mám.“ Název písně Lojza šofér 506 autora Josefa Hrdličky vychází ze skutečnosti, že taxíkáři dříve nosili uniformy opatřené odznaky se služebními čísly. Tato píseň zároveň poukazuje na další často zdưrazňované téma, a to dopravní nehody: „Já jsem šofér, jak vidíte, automobil řídit znám - že to není žádná hračka, taky ale řeknu vám. Můj zjev na ulici nikdy nic dobrého nevěstí, lidi ř́ikaj - ,šofér každý, to je pytel neštěstí. Anděla až zazní trouba, mrtví budou vstávati, ozve-li se moje ale, živí začnou padati. Jak zahouká trouba má, všechno stranou utíká, na koho já vlítnu, hup, ten dostane notný šup!“ Ve dvacátých letech 20. století byly velmi populární různé odlehčené kuplety a písničky na téma cestování automobily obecně, Gössel z nich uvádí např́iklad popěvek Josefa Švába-Malostranského s názvem Nový kuplet benzinový: „Benzin dneska vládne všude v tom nynějším století, bez něho ani aeroplán na metr nedoletí, automobil jím nabumbán kupředu se potácí, ale jak mu dojde benzin, hnedky je po legraci! Kasír jedné velké banky celičký milion šloh, na cestu do Ameriky schystal vše ten čilý hoch, rychle vsednul v automobil by dojel na hranici v kvapu zapomněl však benzin, tak jej čapli strážníci!“ Nebo valčíkovou serenádu Ladislava Lásky Abych si tvé srdce dobyl, koupím já ti automobil, která se dle autora „zpívá se milce pod oknem, možno zpívati i v př́padné masce a kostýmu“: „Abych si tvé srdce dobyl, koupím já ti automobil, bys věděla, že jsem pánem, obdařím tě eroplánem. V něm si sednem vedle sebe a polítnem až do nebe, kde čekají na tebe. Čert aby tvé srdce dobyl - ten at ti dá automobil! Musel bych být mezulánem obdařit tě eroplánem! Raděj udělám si bene, nepolítnem už do nebe, hrom at bací do tebe!" Ve dvacátých letech byly také velmi populární šlágry německého původu, často s dvojsmyslnými verši, známé jako tzv. odrhovačky. Jejich domácí obdobou se staly dvě písně českých autorů Jaroslava Jankovce a Bohuslava Austa na téma automobilů: Za tou naší garáží: „Za tou naší garáží, Manča na mě doráží, má takový divný chutě, že mě to až zaráží. Nechci jí nic slibovat, každý může 
chybovat, když jsem v ráži za garáží, tak si může libovat. Co už se mě tahle Manča za celej den namučí, že až mě ta její láska někdy hejbá se žlučí. Když z ní zrovna jiskry lítaj, když je nejvíc v kuráži, já mám strach, že vod ní chytne jednou benzin v garáži“; a polka s názvem Já viděl Ellu na sentinelu: „Vona s nim jezdí, vode zdi ke zdi.“

Gössel ve svém článku také upozorňuje na dopad rozvoje automobilismu na skupinu maloživnostníků - městských fiakristů. Pro ilustraci uvádí píseň v podání Jindřicha Plachty z roku 1931 vyjadřující pocity drožkáře, který v konkurenci $s$ automobily před sebou nevidí žádnou budoucnost. Jmenuje se Píseň vyhynulého drožkáře, pochází od hudebního skladatele Julia Kalaše a textaře Karla Hrnčíre a zazněla ve filmovém ztvárnění hry dramatika Františka Langera Obrácení Ferdyše Pištory: „Bejvalo, bejvalo a už není, když jsem se projižděl po dláždění -- maminky vozil jsem do plesů, inteligenty a nóblesu. Dnes už mi nikdo neuvěří, jaký jsme mívali pasažéři - protože máš dneska raritu drožkáře vidět na ritu, ted' už se nad náma šeří. Tak už nám, koníčku milý, nadobro odzvonili, tak už jsme oba dva, já i ty, těma autama vůbec ubitý. Tak už jsme, koníčku vraný, zůstali poslední - na štaflu s kočárem budeme sami vzpomínat zašlých dní."V roce 1930 byl v Praze instalován první světelný semafor a jen o pár měsíců později na tuto novinku zareagoval komik Ferenc Futurista v kupletu Jarky Mottla s názvem Vy to jistě víte, v němž o semaforu ironicky zpívá v souvislosti se „světovostí“ našeho hlavního města: „Na všechno tam mají príma fór, rychlý provoz brzdí semafor. "V roce 1936 pak Ferenc Futurista v písničce Kdybych já měl blázinec ztvárnil téma výroby lihobenzinu: „Když se dívám na poměry, tak mě přejde smích - protože je brambor málo, tak z něj dělaj líh. Lihobenzinu ted' máme, až to zaráží, ale auta stojej v garáži.“

Další významnou skupinu písní tvořily podle Gössela ty, které pojednávaly o konkrétních značkách automobilů. Několik světových značek je zmíněno například v kupletu Rudolfa Juristy s názvem Já mám automobil, ten má dvě stě kobyl: „Když do něho vlezu, holku si tam vezu, dělám hlouposti. Walter, Škoda, Packard, Cadillac - my jsme první, oni přijdou pak. Já mám automobil, ten má dvě stě kobyl, čtyři gumy rezervní.“ Značka Mercedes se zase objevuje parodii na tango Jaroslava Ježka Mercedes, Jiří Voskovec a Jan Werich také nazpívali píseň Téměř ztracená renaultka, $\mathrm{v}$ písni Vojtěcha Mertena $\mathrm{z}$ roku 1932 se můžeme dozvědět, že Není laurinka jako Laurinka, Praga Baby se jmenuje píseň Melody Babies z roku 1934.

Automobil se v písních také často vyskytoval v erotizované podobě, jako prostředek k namlouvání či k získání pozornosti žen. Např́ílad ve filmu Děvčátko, neříkej ne hlavní hrdina zpívá: „Madame, můj vůz čeká, jen dvě místa jsou však v něm, madame, snad vás to leká, že sami dva pojedem? Já vím, že mnoho žádám, však věřte, na mou čest: jen cesta ve dvou, madame, tou pravou cestou k štěstí jest!“ V písni s názvem Autotango láká zpěvák pod záminkou vyjíždky autem do soukromí střídavě tři dívky: „Přec znáte mne, jsem čestný muž - zakončíme nenápadným rautem u Zavřela nebo v Chapeau Rouge. A kdyby byl konec třeba ráno, nevíme přec, co může být, nemusíte domů, nevídáno - nabízím vám svůj tichý byt.“
V tangu s názvem Erika nabízí herec Oldřich Nový luxusní automobil dívce se slovy: „Jak slunko svitne dnes, můj mercédes má jen $\mathrm{k}$ vašim službám být. " V písni Copak je to padesátka Antonín Holzinger dámy upozorňuje, že by se neměly zrríkat starších pánů: „Nebot jak se s dámou jednat musí, velmi dobře chápe - vždyt má pro vás $\mathrm{k}$ dispozici $35 \mathrm{HP}$. Proto, dámy, která máte zálusk na Rolls-Royce, horujte jen pro old boys!" Spojení automobilu a mužské přitažlivosti stručně vystihuje text Jaroslava Jankovce a Františka Voborského z roku 1932: „Šoféríi, šoféři, v lásce vám štěstí kvete, šoféři, šoféři, že to tak dovedete - houknete u dveří, holka vám uvěří a vy ji za to zas odvezete."

Jako další kategorii zmiňuje Gössel písničky, v nichž byly automobily pojednávány $\mathrm{z}$ čistě sportovních hledisek. Do této kategorie patří například oficiální hymna klubu majitelů automobilů značky Aero, kterou pod názvem Aero step nazpíval Jára Pospíšil, nebo pochod Tisíc mil, který nahrál a nazpíval R. A. Dvorský s Melody Boys. Svůj článek Gössel uzavírá slovy pochodu branného sboru československých motoristů, který v roce 1938, již v době bezprostředního ohrožení republiky, nazpíval pod názvem Motorová hráz Karel Leiss doprovázený sborem. Autorem hudby byl klavírista Oldřich Letfus, text složil cestovatel František Alexander Elstner: „Žižky hlas vede pevný vozů šik, nás kř́ílly chrání Štefánik. Čekej na rozkaz, motorů zazní hlas, vesele v boj za otčinu! Pevně stůj na své stráži, branný sbor, pamatuj, není času na hovor, máme jeden cíl, jednotu branných sil, spojuje nás vůle k činu“" (Gössel 2004).

Z dalších meziválečných počinů s automobilovou tematikou lze jmenovat ještě písně Automobilista v podání Vlasty Buriana (1932), Balada o hřídeli osmkrát zalomené v podání Kocourkovských učitelů (1931), Já nemám auto od Karla Hašlera (1930), Ferenc se veze v podání Ference Futuristy (1928), Pojd' děvče, já ti koupím zetku od Františka Kreuzmanna (1932) nebo Madame, můj vůz již čeká od Jindry Lázničky (1932). $\mathrm{Z}$ orchestrálních skladeb meziválečné éry se stala velmi proslulou předehra Jaroslava Ježka k revue Osvobozeného divadla Don Juan \& Comp. s názvem Bugatti Step, zkomponovaná v roce 1931 ve stylu ragtimu. Skladba měla být poctou automobilové závodnici Elišce Junkové, která závodila právě $s$ vozem Bugatti.

V období od druhé světové války do současnosti motiv automobilu z české populární hudby nezmizel, naopak průběžně se objevoval $\mathrm{v}$ písních různých žánrů a $\mathrm{v}$ podobných rovinách jako $\mathrm{v}$ předválečném období. Nechyběl automobil erotizovaný, jak vypovídá např́iklad proslulý český remake písně britského skladatele Christophera Dowdena z roku 1972 Long Haired Lover from Liverpool. Českým textem ji opatřil Zdeněk Borovec a nazpívala ji Nad’a Urbánková pod názvem Blondák s červenou bugatkou: „On vám byl blondák s červenou bugatkou, co má lesk jako nový míč, zval mě na drink a na zmrzlinu s oplatkou, no a já jsem $\mathrm{z}$ toho byla celá pryč.“ Automobil jako prostředek sportovní je reprezentován např́íklad písní dua Kamélie z roku 1980 Formule: „Nej největší závod začíná, nej nejlepší jezdce poznává. Sám dábel sám z jízdy hrůzu má. Nej nejlepším já ted' zamávám. Dobrý pozor dej, 
když zatáčkou vůz tvůj prolétá, pozor, poslouchej, nejrychlejší závod vyhrává. Formule s náma závodní dráhou uhání dál, formule s náma a svátek mládí blíží se $\mathrm{k}$ nám. Diváci šílí aaa motory kvílí, formule s náma velký boj právě svádí." Nezáviděníhodný osud partnerky závodníka rallye vyjádřila $\mathrm{v}$ písni Poslední rallye country zpěvačka Věra Martinová: „Měl rád silná auta, hlavně rád v nich závodil, radši měla bych kosmonauta, ten snad by víc se mnou byl.“ Tato píseň se smutným koncem v sobě zároveň spojuje i další časté téma - dopravní nehody: „Z tribun mu každý mával, vítězství měl blízko zas a pak přišla ta ostrá pravá, brzda smyk a př́krý sráz. Dnes nečeká ho sláva, žádné stupně žádný zisk, v novinách vyšla krátká zpráva, další obět bohu jménem risk. "U tematiky dopravních nehod stojí za zmínku svým způsobem výchovné texty, které varují před řízením pod vlivem alkoholu a sugestivně líčí tragické následky takového počínání. Příkladem takovéto tvorby je skladba skupiny Katapult Půlnoční závodní dráha: „Šli na pár piv, bylo jich víc, pak jeden dostal nápad, v autě se svízt. Půlnoční závodní dráha, kvílení rychlých kol. Půlnoční závodní dráha, tam jezdí alkohol. Brzdy a smyk, rána a křik, a pak jen prázdné ticho, a víc už nic." Podobný motiv se vyskytuje také ve skladě Don't drink and Drive skupiny Tři sestry, která vyšla $\mathrm{v}$ roce 1991 na albu Alkáč je největší kocour: „Mixy koly, rumu, ledu otupily schopnosti, kdo moh tušit, že má přednost dědek na tom rozcestí? Neř́íkej nic, vím, to bolí, ty máš vnitřní zranění, sestř̌ičce dám tvoje koly, pomeranče taky sní. Don’t drink \& drive, don't don’t drink \& drive.“ Z dílny Tř́ sester pochází také skladba Taková malá nehoda inspirována nehodou zpěvačky Ilony Csákové, při které v roce 1999 na dálnici D1 nezvládla své Volvo v rychlosti kolem 130 kilometrů v hodině a obrátila ho na střechu, přičemž naštěstí vyvázla téměř bez zranění: „Když jsi píchla o půlnoci vprostřed temných lesů, zřejmě ti to nepomůže, že jsi první v Esu. Kolo vyndat neumíš a networek šel spát, můžeš čekat na zázrak a na silnici stát. Paví boa nehřeje tak, jak by mělo hřát, měla radši kožíšek sis na Vánoce přát. Zděšený a nervózní je kabelkový pinč, takhle by to nenatočil ani David Lynch."

Novodobá česká hudební tvorba se také může pyšnit pestrou škálou vesměs vtipných písní o nejrůznějších značkách automobilů. Hned několik značek se objevuje v písni Auta autorské dvojice Jaroslav Uhlír a Zdeněk Svěrák: „Jede, jede Ford a v něm sedí lord. Jede, jede Mazda, řídí ji pan Brázda. Jede Mitsubishi, veze čtyři myši. Jede, jede Toyota, liška veze kojota. Jede, jede Tatra, po které se pátrá. Jede, jede Praga a v ní baba Jaga. Jede Felicie podél řeky Dyje. Jede, jede Saab a v něm sedí čáp." V roce 1960 spatřila světlo světa optimistická píseň Aerovka červená z dílny skladatele Zdeňka Petra a textaře Zbyňka Vavřína, kterou nazpíval Rudolf Pellar: „Já vím, kdo způsobil, že je dnes plno jara. Alenka v kočárku se hihňá do dlaní. Cink, cink a ratata, to moje stará kára, aerovka červená, ulicí uhání, cink, cink a ratata, ulicí uhání." Své zastoupení má automobil také v repertoáru dua Těžkej Pokondr, které je známé parodujícími remaky známých zahraničních písní. Hit Felicita italského popového dua Al Bano a Romina Power nazpívali pod názvem Felicie: „Felicie - no to je super kára, nejlepší fára jsou. Felicie - vyráběj se i dízly, když po- tkáš fízly, maj Felicie - to je sedan či kombi, obě jsou bomby ty Felicie, Felicie." Ódu na vytrvalost a spolehlivost dalšího zástupce značky Škoda - Škodu 1000 MB zkomponoval český písničkář Slávek Janoušek (narozen 1953): „Řeknu vám to otevřeně. Ve škodovce tisícovce jezdím denně. A furt to jede, furt to jede, furt to jede. Furt to jede, zas to jede. Holt poctivá stará česká ruční práce. Na koleně na koleně. A furt to jede, furt to jede, furt to jede. Furt to jede, zas to jede. Sice nebliká to, netroubí to. Vaří se to, netopí to. To nebudu lhát. Ale jede Škoda 1000 MB. Z roku pětašedesát.“ Několik značek automobilů také zakomponoval do svých písní zpěvák, skladatel, textař a humorista Ivan Mládek. Také on věnoval jednu ze svých písní Škodě 1000 MB. V písni Embéčko vyznává smutek nad blížící se ztrátou svého starého věrného automobilu: „Ach, ty mý embéčko, bolí mě srdéčko, musím tě do šrotu dát, máš jen dva výbrusy, tedka tě na kusy rozřežou, chce se mi řvát.“ Touha zvýšit si společenskou prestiž prostřednictvím nového automobilu je vyjádřena $\mathrm{v}$ písni Džínový velorex: „Ušetřím na nový velorex džínový, mají ho v Tuzexu v Praze. Děvčata ve Zbečně zaberou konečně, Tưmovou ulovím snáze. "Vzpomínkou na legendární vůz Praga je píseň Pragovka baby: „Pragovky, baby, žádná není na skladu, všechny už jsou dávno pryč, i ty z výkladu. Pragovky, baby, nejsou a nebudou, padesát let nepřišly a už nepřijdou. Na vtípky nemám náladu, nemáte-li na Ladu, nezdržujte práci naší mototechny. Prosím vás pragovka, baby, zastaralý je to kus, zbytečně moc najezdí, neví, co je šlus.“ Německý automobil DKW (Dampf-Kraft-Wagen) se objevuje v kuriózním popěvku Zkratky pojednávajícím o běžných motoristických strastech: „Z PLR do MLR jel jsem přes ČSSR, SNB mé DKW si stoplo na TK. Mé DKW SPZ ABT 25 - 50 musí ted'ka na GO do ČSAO. OHC či OHV či co má to $\mathrm{DKW}$, potřebuje $\mathrm{z}$ NDR nová šoupátka. Jsem RNDr. CSc. z ČVUT v Praze 2, v ČSAO v Praze 3 já mám tlačenku." Vzhledem k velkému množství zkratek, které už dnes patři daleké minulosti, byl zpracován text také do „rozzkratkované“ verze: „Z Polské Lidové Republiky do Mad’arské Lidové Republiky jel jsem přes Československou Socialistickou Republiku, Sbor národní bezpečnosti mé Dampf-Kraft-Wagen si stoplo na technickou kontrolu. Mé Dampf-Kraft-Wagen státní poznávací značky Á Bé Té dvacet pět padesát musí ted'ka na generální opravu do Československých autoopraváren. Over Head Camshaft či Over Head Valve či co má to Dampf-Kraft-Wagen, potřebuje z Německé Demokratické Republiky nová šoupátka. Jsem rerum doctor naturalis candidatus scientiarum z Českého vysokého učení technického v Praze 2, v Československých autoopravárnách v Praze 3 já mám tlačenku“ (Necyklopedie, 2012). K známým Mládkovým hitům $s$ automobilovou tematikou patří také Koukejte vycouvat pojednávající o hádce dvou řidičů - primáře kliniky a profesora matiky: „Když ten chlap odešel, odplaty čas nadešel, já jemu s korunou auto obešel. Č́ihal však za rohem, čekal, jak se zachovám, přešel mi po střeše, $\mathrm{z}$ auta ruinu mám. A tak primář kliniky s profesorem matiky váleli se po zemi, žádný cavyky. Oba starší pánové, po té, když je zabásli, po právu si přibližně stejně vyfásli.“ $V$ české country a folkové tvorbě se značka automobilu vyskytuje například v písni Jana Vyčítala 
Cadillac pojednávající o touze dělníka General Motors pořídit si svůj vysněný vůz: „Můj děda byl toulavej pták, toulal se světem, no, a tak ho jednou osud do Detroitu svál, tam auta dělal na pásu, ty pro rychlost i na krásu, pro pány z firmy Motors General. Vždycky, když bral vejplatu, dluhy odečet' a outratu, viděl, že i kdyby hodně mák', mínus vždy zbude, a ne plus, že nikdy neušetř́i na ten vůz, co je tu dělal: značky Cadillac.“ Od stejného interpreta je také píseň Pivní džíp o autu jezdícím na pivo místo benzinu: „Já nosil pivo v lavoru pro tuhle pivní potvoru, jen když měl nádrž piva plnou, jel, benzin prudce odmítal, to se jak zvíre zazmítal, jenom pípu za čerpadlo měl.“ $\mathrm{Na}$ country a folkové scéně se staly oblíbenými především takzvané truckerské písně o řidičích kamionů a nákladáků, jejich toulavém životním stylu, dalekých cestách, hrdinství, nadějích a zklamáních. $Z$ české tvorby v tomto směru lze jmenovat např́klad píseň Michala Tučného Mám páru: „Mám páru, mám páru, mám v tom fáru mám páru. Jel jsem takhle jednou s károu silnicí, ta dívka mávla a já jsem na fleku stál. Dívka nastoupila, já sešlápnul jsem plyn, $v$ jejích očích záblesk zájmu hrál. Ten př́iběh má však háček, jak jen nerad přiznávám. Dost! řekla přísně, tuhle píseň znám. Chlapů v nákladáku je víc než na nebi mraků a každej z nich je stále na cestách sám a sám, a říká: Mám páru. “ Za zmínku jistě stojí také dojemně laděná píseň v podání Josefa Laufera Sbohem lásko, já jedu dál, jejíž hrdina - řidič kamionu tráví na cestách tolik času, že dá jeho přítelkyně přednost jinému muži: „Šedá dálnice a náklad za zády, je můj svět, který někdo zmapoval, svět tiráků, skoupý na parády, sbohem, lásko, já jedu dál. Nalej mi, kamaráde plnou. Tak už to bývá. S kytkou jsem po čtyřech schody bral, věř mi, věř mi, že zvonil jsem dlouho. Pak s ní ve dveřích cizí chlápek stál, tak jsem řekl jen: Sbohem lásko, já jedu dál.“ Proč muži řídí nákladák, se zamýšlí Petra Černocká v písni Nákladák: „Měl v ramenou víc, než se zdá a v očích místa vzdálená. Jak noční stín svůj trajler hnal na plný plyn stále dál a dál. Snad řek mi víc než dnes já vám Když vez mě tmou až bůhvíkam A možná ví, proč létá pták, proč muži řídí nákladák." Zdařilou parodií na toto téma je píseň ve stylu americké country Jack Jag, kterou herec a zpěvák Jiří Macháček zpívá v zábavné one-man country show v divadle Sklep. Oblíbenou skladbou řidičů z povolání je také píseň českého country zpěváka a textaře Ladislava Vodičky Řidič, ten tvrdej chleba má: „Já jsem najezdil tisíce kilometrů, a můžeš mi věřit, když ti tady povídám, řidič ten tvrdý chleba má. Musí znát volant, brzdy, spojku a plyn, válce, písty, a rychlostní skř́ín, chladič, čerpadlo, diferenciál, sytič, karburátor, rozdělovač, kondenzátor, hlavu, ventil, baterie, stěrače, duše, pneumatiky, pera, tlumiče, šasi, svíčky, hřídel a blok, ložiska, poloosy, lanka, ojnice, trysky, přerušovač to dobrej řidič zná, já vím že řidič tvrdej chleba má.“

$\mathrm{V}$ textech různých alternativních skupin se pak automobil stal objektem společenské kritiky, at' už v souvislosti s dopadem automobilismu na životní prostředí nebo kritikou životního stylu bohatých. Pro ilustraci lze jmenovat naprríklad píseň punkové skupiny Visací zámek Hodně je aut: „Dlouhý krátký černý barevný Nejluxusnější i levný Každej den každou noc Jedou, jedou, jedou. Každej den každou noc. Ženou se za se-

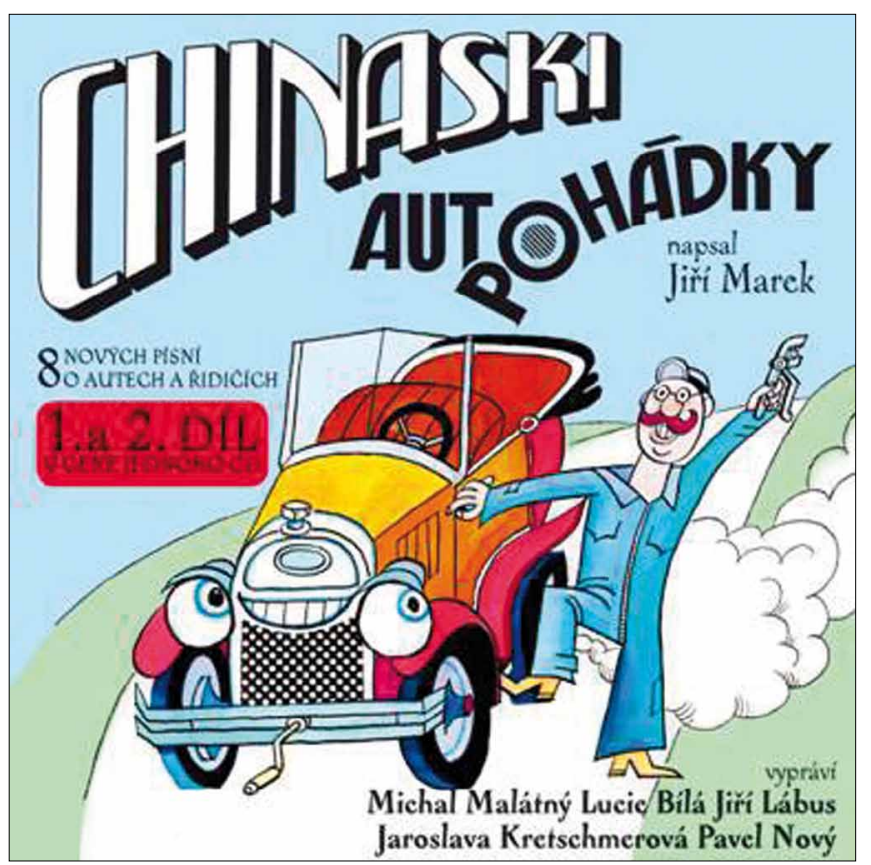

Obr. 11. Autopohádky skupiny Chinaski z roku 2004. Pramen: http://www. people.cz/mag/cs/articles-detail/aid-12210

bou Ženou se proti sobě Tů tů tutututů Hodně je aut Tů tů tutututů."

V české populární hudbě nechybí ani motiv radosti z automobilu jako takového a z jízdy v něm, jak ukazuje např́klad píseň Věry Martinové Mám káru: „Já mám káru, v tý jsem v páru, tak se vejdem já a láska má, tam jsem $\mathrm{v}$ páru, $\mathrm{v}$ krásným fáru, tam se vejdem kytara a já. Když motor nestačí, tak někdo zatlačí a vůz vzhưru stoupá, a to vám př́ísahám, že z kopce jede sám a nás pěkně houpá. “ Helena Vondráčková interpretuje podobný motiv radosti $\mathrm{v}$ remaku písně Whitney Houston I Wanna Dance with Somebody otextovaném pod názvem Mám nový vůz: „Mám nový vůz! To jsou zprávy! Mám zbrusu nový vůz. Mám nový vůz! barvy trávy. Já se z něho snad zblázním! Tišší než myš, když kupředu sviští svůdně dálnicí. A z jeho křesel je cítit plyš a je vždycky tak nad věcí."

Specifický okruh v rámci tvorby s automobilovou tematikou tvoři písně na albu skupiny Chinaski Autopohádky z roku 2004 (obr. 11), kde můžeme najít například skladby Chrysler, Porsche 911 či Kola a kapoty. Skupina Chinaski na tomto albu zároveň převedla knihu motoristických pohádek „Autopohádky“ Jiř́iho Marka z roku 1958 do audio podoby a namluvila postavy $\mathrm{z}$ těchto pohádek. $Z$ dílny skupiny Chinaski stojí v této souvislosti za zmínku také píseň Duše z gumy opěvující vztah řidiče a jeho věrného automobilu: „Mám duši z gumy a boky plechový, jsem jenom dopravní prostředek kolový, mám duši $\mathrm{z}$ gumy a srdce $\mathrm{z}$ ocele, přesto ho miluji řidiče přítele."

\section{HUDEBNÍ VIDEOKLIPY}

Motiv automobilu pronikl nejen do textů písní, ale také do hudebních videoklipů. Automobil je ve videoklipech motivem 
mimořádně častým, a to nejen u písní s ryze automobilovou tematikou. Mezi režiséry videoklipů je obecně velmi oblíbeným ztvárněním interpret nebo rovnou celá kapela zpívající v jedoucím voze. O klasických klipových klišé se zmiňuje např́iklad reportáž z roku 2001 s názvem „Klipy z jedoucího auta“ uveřejněná na webových stránkách www.stream.cz. Takovým prŕkladem, který je zde uváděn, je třeba videoklip Ironic z roku 1996 od již výše zmiňované kanadsko-americké zpěvačky Alanis Morisette. Jeho děj se odehrává v limuzíně Lincoln Continental Mark V a zpěvačka si zde zahrála několik vzájemně komunikujících postav. Celá čtyřčlenná americká hard rocková kapela Audioslave byla v roce 2002 umístěna do automobilu Dodge Challenger v klipu Show Me How To Live. Efektní video je ale prostř́hané částmi z filmu Vanishing Point a zpěvák skupiny ve skutečnosti řídí jen $\mathrm{v}$ relativně klidných částech, kdy se automobil prohání na silnici uprostřed pusté krajiny. Ve videoklipu k písni Karma Police britské alternativně-rockové skupiny Radiohead, který vznikl v režii Jonathana Glazera v roce 1997, se objevuje frontman kapely Thom York, jak sedí na zadním sedadle automobilu Chrysler New Yorker (model 1996) a madarský herec Lajos Kovács, který je oním automobilem venku pronásledován. $\mathrm{Na}$ konci děje se ale situace změní poté, co si Kovács všimne, že z vozu uniká benzin - nenápadně zapálí za zády sirku, kterou vhodí na vyteklé palivo. Řidič automobilu se marně pokouší uniknout a videoklip končí pohledem na hořící interiér a zadní sedadlo, na kterém již Thom York ale nesedí. Zajímavostí videoklipu je, že téměř všechny záběry jsou snímané $\mathrm{z}$ pohledu řidiče, o kterém se však $\mathrm{v}$ průběhu děje nic nedozvíme. Ve videoklipu k hitu My Favorite Game (1998) od švédské skupiny Cardigans se objevuje zpěvačka Nina Persson (narozena 1974), která jako řidička automobilu Cadillac Eldorado 1974 porušuje všechny možné dopravní předpisy, najíždí do nesprávného pruhu a znemožňuje plynulou jízdu ostatním řidičům, jejichž auta často následně havarují. Zpěvačka ničivé následky svého jednání nevnímá a pokračuje ve své zběsilé jízdě. Na konci videoklipu se pak postaví na sedačku a rozevírá náruč, aby přivítala smrt v nárazu na protijedoucí auto. Její tělo je poté vymrštěno, ale zakrvácená zpěvačka se probírá a chce se zvednout a odejít. Nicméně po chvíli na ni dopadá kámen, který si vložila do automobilu na začátku děje písně a umírá7. Mezi další klišé videoklipů, kde hraje automobil hlavní roli, je řazena píseň americké skupina Red Hot Chilli Peppers Scar Tissue z roku 1999, která v roce 2000 získala ocenění Grammy pro nejlepší rockovou skladbu. Automobil, který řídí kytarista skupiny John Frusciante (narozen 1970), je Pontiac Catalina, model z roku 1967. To, že je to zrovna Frusciante, kdo řídí automobil (ačkoli sám $\mathrm{v}$ době natáčení nevlastnil řidičský průkaz), metaforicky vyjadřuje kytaristův návrat do skupiny v roce 1998 po léčbě z drogové závislosti. Mezi další nejznámější automobilové hudební videoklipy patří

7 Píseň má nicméně několik verzí alternativních konců, kde např́klad zpěvačka zůstává ležet na silnici ve žhnoucím slunci, v jiné verzi se jí podaří vstát a z místa nehody odchází se zakrvácenou tváří, $\mathrm{v}$ další bez jakéhokoli zranění pokračuje v řízení automobilu. například duet Desert Rose britského zpěváka Stinga (vlastním jménem Gordon Matthew Thomas Sumner, narozen 1951) s Alžířanem Cheb Mamim (vlastním jménem Ahmed Khelifati Mohamed, narozen 1966). V úvodu videoklipu Sting projíždí Mohavskou pouští v automobilu značky Jaguar S-Type, aby se následně dostal do nočního klubu v Las Vegas a vystoupil společně s Mamim. Stingova Desert Rose byla následně také používána $\mathrm{v}$ reklamních upoutávkách právě na automobily Jaguar ( $v$ roce 2000 byly uváděny půlminutové a minutové verze reklamních spotů, které nesly označení „Sting S-Type").

K nejúspěšnějším videoklipům roku1994 se řadí píseň Crazy od americké rockové skupiny Aerosmith. Ústředními postavami děje jsou dvě středoškolské studentky, které utečou ze školy a vydávají se na projíždku v tmavě modrém Ford Mustangu. Video, ve kterém si zahrála jednu ze studentek tehdy ještě nepř́liš známá dcera frontmana kapely Liv Tylor, obsahuje sugestivní sexuální scény s lesbickým podtextem. $\mathrm{V}$ závěrečné části videoklipu dívky projíždějí kolem fešného a svalnatého traktoristy, kterého pozvou k sobě do auta a společně se vydávají vstříc dalším bláznivým dobrodružstvím.

Z roku 2001 pochází kontroverzní videoklip americké zpěvačky Madonny What it Feels Like for a Girl, který byl režírován jejím tehdejším manžel Guyem Ritchiem. Ve videoklipu, který byl v některých zemích zakázán, představuje Madonna agresivní ženu s kriminálními sklony. Zpěvačka v úvodu písně ukradne žlutý Chevrolet Camaro a vyzvedává z pečovatelského domu starou ženu, se kterou se vydává do ulic města Los Angeles. Během následujícího děje pak obrací svůj vztek zejména proti mužům - najíždí do auta mladíků, kteří se na ni usmívají z vedlejšího vozu, okrade muže, jenž si vybírá peníze z bankomatu či vjede do skupiny chlapců, kteří hrají hokej atd. $\mathrm{V}$ závěru videoklipu pak sama $\mathrm{v}$ plné rychlosti narazí do sloupu.

Samostatným tématem $\mathrm{v}$ hudebních videoklipech je jízda $\mathrm{v}$ lowriderech, o kterých jsme se již zmiňovali výše. Jsou to zejména hiphopová videa s rozhoupanými, až poskakujícími automobily, nicméně průkopníkem byl videoklip k písni Low Rider od skupiny War z roku 1975. Dalšími následovníky tohoto stylu byli $\mathrm{v}$ počátku 21 . století rovněž zde zmiňovaní Cypress Hills - jejich auta pak oproti sedmdesátým létům umožňovala díky výkonnějším tlumičům efektivnější (z našeho pohledu možná až komické) rozhoupání vozu. Určitým posunem v daném žánru je pak videoklip Poor Man’s Hydraulics z roku 2008 amerického rappera E-40 (vlastním jménem Earl Stevens, narozen 1967), kde navádí, jak si vyrobit nákladný lowrider i bez hydraulického zařízení - stačí prý přidat plyn a pak dupnout na brzdu, což je ve videoklipu názorně ukazováno.

V českých zemích se hudební videoklipy jako audiovizuální díla, jejichž zvukovou složku tvoří záznam písně, rozšírily zejména od osmdesátých let 20 . století, nicméně jejich předchůdce můžeme najít již koncem padesátých let. $Z$ české scény je možné jako zástupce tohoto typu ztvárnění jmenovat například videoklipy k písním Mám jednu ruku dlouhou skupiny Buty (1994) nebo Für immer Jung Karla Gotta a německého 


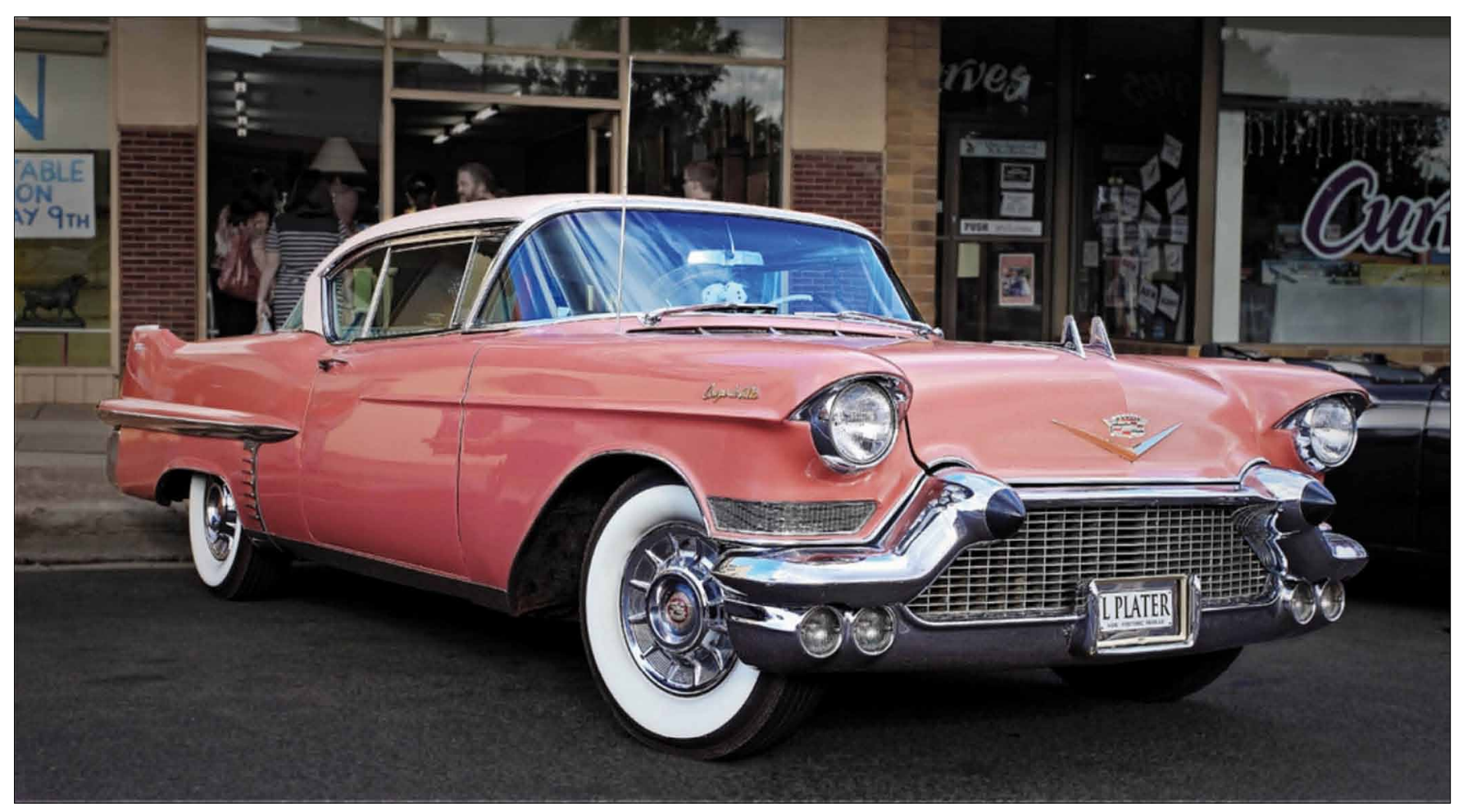

Obr. 12. Růžový Cadillac, který vlastnil Elvis Presley. Pramen: http://www.flickr.com/photos/8773698@N03/4295382970/lightbox/

rappera Bushida (2008). Klip k písni Mám jednu ruku dlouhou je v podstatě sestřihem $\mathrm{z}$ celovečerního filmu Jízda, který natočil režisér Jan Svěrák v roce 1994 a je jakousi poctou slavnému americkému filmu Bezstarostná jízda. Hlavní hrdinové Radek a František se prohání po okresních silnicích jižních Čech v automobilu Mazda 626 první generace, který svérázným způsobem upravili na kabriolet. Užívají si léto, svobodu a flirtování s půvabnou stopařkou, která je na útěku před svým žárlivým př́telem. Videoklip z roku 2008, ve kterém vystupuje duo Bushido a Karel Gott, se váže k remaku hitu skupiny Alphaville Forever Young, který přezpíval Karel Gott jak $\mathrm{v}$ češtině (Být navždy mlád), tak v němčině (Für immer jung). $\mathrm{V}$ klipu se pravidelně střídají záběry interpretů zpívajících ve studiu a v jedoucím automobilu, Karel Gott jede ve starém typu Mercedesu a Bushido v novém, načež se v závěru klipu minou na jedné $\mathrm{z}$ křrižovatek. $\mathrm{V}$ některých videoklipech je sice zachován motiv interpreta $\mathrm{v}$ jedoucím automobilu, nicméně automobil je zde zobrazen jako méně dokonalý vůči jinému dopravnímu prostředku. Tak je tomu např́iklad v klipu $\mathrm{z}$ roku 1961 k písni Milana Chladila Dva roky jezdím bez nehod, kde zpěvák řídí po boku půvabné dámy kabriolet Škoda Felicia a je dostižen hercem Jaroslavem Šterclem na mopedu Stadion S11. Ten se zpěvákem v kabrioletu drží tempo a vede s ním vtipnou konverzaci, která doplňuje text písně. V závěru klipu pak moped řidiči kabrioletu nenávratně mizí z dohledu za závorami na železničním přejezdu. Helena Vondráčková zase v hudebním televizním pořadu Báječné ženy na létajících strojích z roku 1978 marně v automobilu stíhá svého milého letce, který se nad ní vznáší ve dvouplošníku. Humornou českou formou motoristických klipů jsou pak klipy odehrávající se na korbě nákladního automobilu. V klipu k písni Čtrnáct Kubíků Ivan Mládek postupně sbírá čtrnáct bratrů Kubíků na korbu své Tatry, aby je poté vyložil v restauraci U Rotundy: „Na dopravní vyhlášku já ale dbám, čtrnáct Kubíků na korbě mám, ano, čtrnáct Kubíků na korbě mám. Po desáté bylo by už pozdě, bojuju vo sekundy, čtrnáct Kubíků já musím složit v restauraci U Rotundy." Ve videoklipu k písni Pijánovka od skupiny Tři sestry hrají a zpívají všichni její členové na korbě nákladního auta jedoucího po dálnici D1 směrem na Brno. Cestou postupně sbírají stopařky, nejdřív skupinu tř́ vesnických dívek, poté tři zdravotní sestřičky, nakonec tři jeptišky a na korbě propuká bujaré veselí.

\section{HUDEBNÍ IKONY A JEJICH AUTA}

Alespoň v krátkosti se nelze nezmínit o některých významných hudebnících a jejich automobilech. Byl to zejména rock and rollový král Elvis Presley (1935-1977), který byl znám svým nakupováním automobilů ve chvílích, kdy na něj přišly abstinenční prríznaky. Svůj rekord učinil v červenci 1975, kdy přibližně za 140 tisíc dolarů nakoupil čtrnáct cadillaců pro své prrátele, rodinné prŕslušníky a jeden dokonce i pro úplně cizí osobu. Mezi Presleyho nejoblíbenější automobily patřil např́klad Cadillac Fleetwood 60 Special 1955, který si jako jedno z mála aut ponechal. Symbolem jeho hudební kariéry v 50. letech se stal žlutý kabriolet Eldorado. Další proslavený automobil Elvise Presleyho byla limuzína Cadillac Series 1975 Fleetwood. Díky speciálním úpravám měla limuzína pozlacené doplňky, mezi nimiž byly např́iklad telefon, čistič bot či 


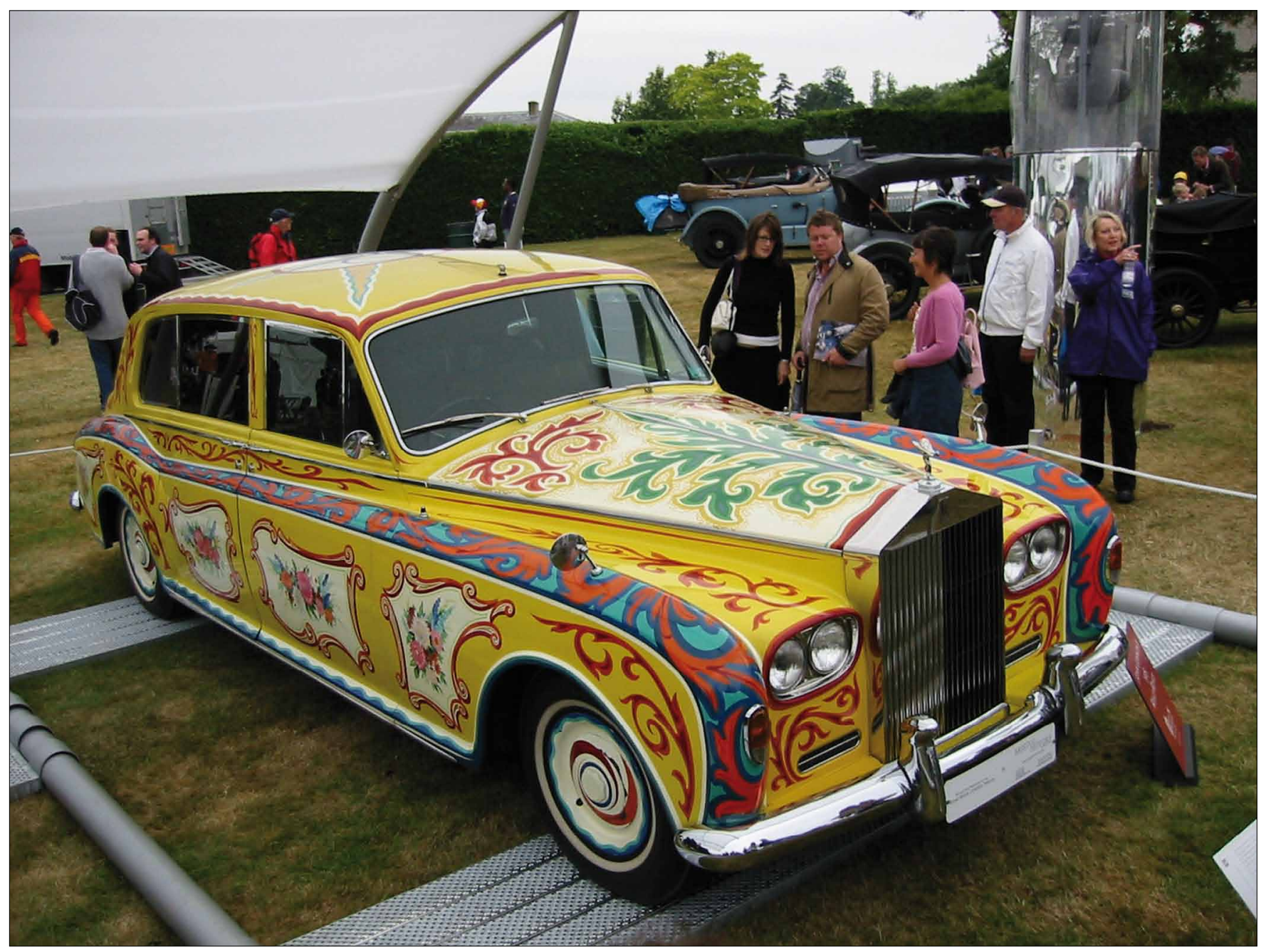

Obr. 13. Rolls-Royce Phantom Johna Lennona. Pramen: http://en.wikipedia.org/wiki/File:JohnLennonRR.jpg

lednička. Kryty kol, přední maska a rámečky světlometů byly pozlaceny čtyřiadvacetikarátovým zlatem. Presley tento automobil používal počátkem 60. let, poté ho prodal gramofonové firmě RCA, která ho následně začala používat pro reklamní účely (obr. 12).

Takzvané psychedelické Porsche (Porsche 356c Cabriolet, model z roku 1965) je spjato se zpěvačkou Janis Joplin (viz výše). Ta za něj v roce 1968 zaplatila 3500 dolarů. Původní barva automobilu byla bílá, ale Joplin si přála něco extravagantnějšího, a tak si na něm nechala vytvořit dramatický design. Automobil se brzy stal symbolem zpěvačky, a pokaždé, když s ním někde zaparkovala, přivolal zájem fanoušků.

Člen slavné skupiny Beatles John Lennon (1940-1980) zase vlastnil Rolls-Royce Phantom (obr. 13). Na svou dobu až př́iliš moderní automobil si zpěvák pořídil v roce 1965 . K vozu byla mimo jiné dodávaná brožura s instrukcemi pro řidiče, jak správně s vozem zacházet. Mezi nimi např́iklad: „Nikdy neparkujte auto pod stromem. Ptáci by totiž mohli zašpinit nejen lak auta, ale i večerní šaty vaší pani" (www.autostylonline.cz). Podobně jako Joplin připadala zpěvákovi původní barva automobilu prŕliš všední, a tak si ho přizpůsobil svoji osobnosti a nechal ručně vyzdobit zářivými barvami.

Také mezi českými hudebníky a zpěváky se stejně jako v zahraničí najde řada těch, mezi jejichž koníčky patří krásná a rychlá auta, která dotváŕí jejich image. Karel Gott (narozen 1939) má na internetových stránkách svého fan clubu přímo samostatnou rubriku věnovanou jeho automobilům. Do roku 2009 jich průběžně vlastnil celkem 27. Nejčastěji měl Mercedes-Benz, ale do jeho vozového parku patřil i Saab, Opel, Alfa Romeo, Honda, Audi, BMW, Porsche nebo Toyota. Karel Gott je milovníkem rychlých aut, ovšem z praktických důvodů dává př̀ednost větší pohodlné limuzíně a o sportovních autech říká: „Každý milovník rychlých aut touží jezdit sportákem. Také jsem to několikrát zkusil, ale nikdy mi to nevydrželo dlouho. Měl jsem sice pocit svobody a výjimečnosti, ale to bylo všechno. Můj sportovní vůz Porsche Carrera měl motor vzadu a při jízdě jsem neslyšel muziku. Když byla mokrá vozovka, musel jsem pořádně zvolnit. Byl to jiný druh jízdy, v zatáčkách se chtělo motoru vždycky dopředu. Firmy, které dodávají sportovní vozidla, dělají pro koupěchtivé zákazníky zkušební jízdy a učí je, jak se chovat v zatáčkách, př́i smyku a podobně. To jsou prostě zápory sportovních aut. Sportáky 
mi nevyhovují také proto, že mají malý kufr, do kterého se nevejdou žádná zavazadla. Navíc si nemohu za sedadlo pověsit kostýmy. Proto jsem si už radost ze sportovní jízdy odepřel“ (Karel Gott 2012).

Zpěvák a skladatel Daniel Landa (narozen 1968) závodí v autech na profesionální úrovni. Od roku 1996 úspěšně jezdil autokros, $\mathrm{v}$ roce 1998 obsadil 6. místo $\mathrm{v}$ Evropě. V roce 1999 byl vyhlášen nováčkem sezony mezi trucky a v roce 2000 byl pátý na mistrovství Evropy v truck racingu. V roce 2001 opustil dráhu pilota trucků a usedl do vozu v soutěži rallye. V současné době jezdí rallye $\mathrm{v}$ kategorii N4. Jeho aktuálním závodním vozem je Mitsubishi Lancer Evo IX skupiny N4. Před ním jezdil v Lancerech generací VI a VII a krátce si ozkoušel Toyotu Celica GT-Four, Ford Escort RS Cosworth a Škodu Octavia WRC (vše skupina A8). (Daniel Landa, 2012).

Velmi populárním motoristou na české hudební scéně se $\mathrm{v}$ posledních letec stal moderátor a zpěvák Leoš Mareš (narozen 1976) díky svému rudému Ferrari 360 Modena (obr. 14), o kterém se ř́ká, že je neslavnějším Ferrari u nás. Bylo vyrobeno v roce 2002 a umí jet rychlostí až 296 kilometrů za hodinu. Ještě před tím, než ho Leoš Mareš koupil, měl prý jeho model dlouho vystavený u lůžka. Popularitu svého auta ještě zvýšil tím, když ho v roce 2011 prodal své domovské rozhlasové stanici Evropa 2, která pak z Marešova Ferrari udělala první cenu v posluchačské soutěži. Leoš Mareš je však nechvalně známý také častými dopravními nehodami, při kterých několikrát naboural i své milované Ferrari, nejvážněji v roce 2004 nedaleko Českých Budějovic.

K známým milovníkům rychlosti v minulosti patřil také textař Jiří Štaidl (1943-1973), bratr hudebníka Ladislava Štaidla, mimo jiné autor celé řady textů k slavným hitům Karla Gotta. Byl známý bohémským stylem života, četnými vztahy s atraktivními ženami a láskou k rychlým autům. Často řídil pod vlivem alkoholu a bez zapnutého bezpečnostního pásu. $\mathrm{V}$ roce 1973 se mu stala osudnou cesta za rodiči do Jevan, když nedaleko Říčan pod vlivem alkoholu smrtelně havaroval ve svém Renaultu 17. Jiří Štaidl se v roce 2011 stal hlavním hrdinou divadelní hry Zaslíbení brněnského Mahenova divadla. Hra pojednává o jeho vztahu se slavnou českou krasobruslařkou Hanou Maškovou, která paradoxně zemřela také při nehodě ve svém voze Opel GT o rok a půl dříve.

Smrt v automobilu potkala i několik dalších osobností z české hudební scény. V létě roku 1985 se stal obětí automobilové nehody mladý popový zpěvák Petr Sepéši (1960-1985), když se cestou z Prahy za svými rodiči do Aše srazil ve voze Škoda $100 \mathrm{~s}$ vlakem na železničním přejezdu ve Františkových lázních. V lednu 1996 zasáhla vážná ztráta skupinu Tři sestry. Cestou z lyžařské dovolené ve Francii tragicky havaroval několik kilometrů za Rozvadovem bubeník Jiří Brábník přezdívaný Hadr. Jiří Brábník byl jedním ze zakladatelů a hlavních pilírư skupiny, podle mnohých i původce jejího názvu, taktéž však milovník aut a majitel autobazaru. Zahynul po smyku a následném nárazu do stromu ve svém žlutém Porsche Carrera, které však v okamžiku nehody sám neřídil, jel jako spolujezdec na zadním sedadle. V roce 2004 zemřel na dálnici D1 krátce před svými třiadvacátými narozeninami muzikálo-

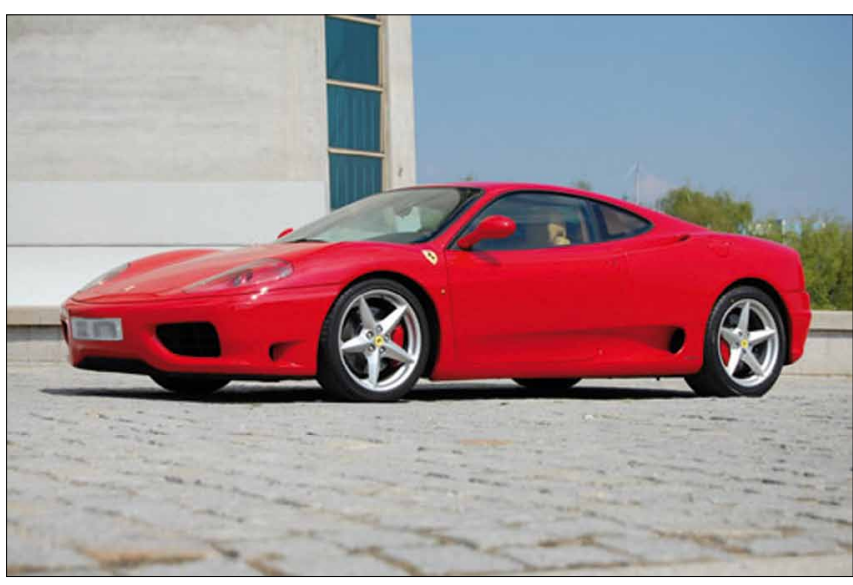

Obr. 14. Ferrari Leoše Mareše jako první cena v posluchačské soutěži radia Evropa 2. Pramen: http://www.evropa2.cz/cs/jednouzazivot/fotogalerie. shtml

vý zpěvák Patrik Stoklasa (1981-2004), který se do povědomí veřejnosti dostal účastí v pěvecké soutěži „Česko hledá superstar“. Spolu se zpěvákem Karlem Černochem a jejich řidičem se vraceli $\mathrm{z}$ pěveckého vystoupení pořádaného $\mathrm{v}$ Olomouci v rámci předvolební kampaně ČSSD. Havarovali ve voze značky Mercedes Vito, který se srazil s dodávkou. Další obětí dopravní nehody se stala v červenci 2007 muzikálová zpěvačka, tanečnice a autorka šansonových recitálů Pavla Kapitánová (1970-2007), když se společně se svou manažerkou vracela z koncertu v Rumburku. Na dálnici D8 do jejich vozu Opel Astra bočně narazil jiný osobní vưz a následně pak dodávka. $\mathrm{Na}$ následky nehody zemřely obě ženy, po Pavle Kapitánové zůstala tehdy roční dcera.

\section{HUDBA S AUTEM}

Další rovinou vztahu hudby a automobilu je situace, kdy se sám automobil stává hudebním nástrojem. O několika takových experimentech se zmiňuje naprríklad Tomáš Procházka ve svém článku Automobil. Uvádí zde počin japonských vědců $\mathrm{z}$ Hokkaido Industrial Research Institute, v jehož rámci bylo upraveno několik silnic $\mathrm{k}$ hudební produkci. Takto upravené silnice byly označeny symbolem noty a opatřeny systémem zářezů do povrchu vozovky. Při doporučené rychlosti $45 \mathrm{~km} / \mathrm{h}$ byl pak slyšet uvnitř automobilu hudební tón. Procházka se rovněž zmiňuje o využití automobilu jako části hudebního nástroje. Takovým př́kladem může být reklamní kampaň na automobil Ford Focus, kde symfonický orchestr hraje na 21 hudebních nástrojů vyrobených ze součástek tohoto vozidla.

Vedle toho se automobilka Honda v roce 2011 ve své reklamní kampani s podtitulem Honda: The Power of Dreams snažila za pomoci smíšeného sboru napodobit zvuky propagované značky automobilu.

Další formou jsou pak samotné hudební projekty, v jejichž hudebním vystupování se klade důraz na využívání automobilových součástí. Se sloganem Reduce-Reuse-Recycle vystu- 


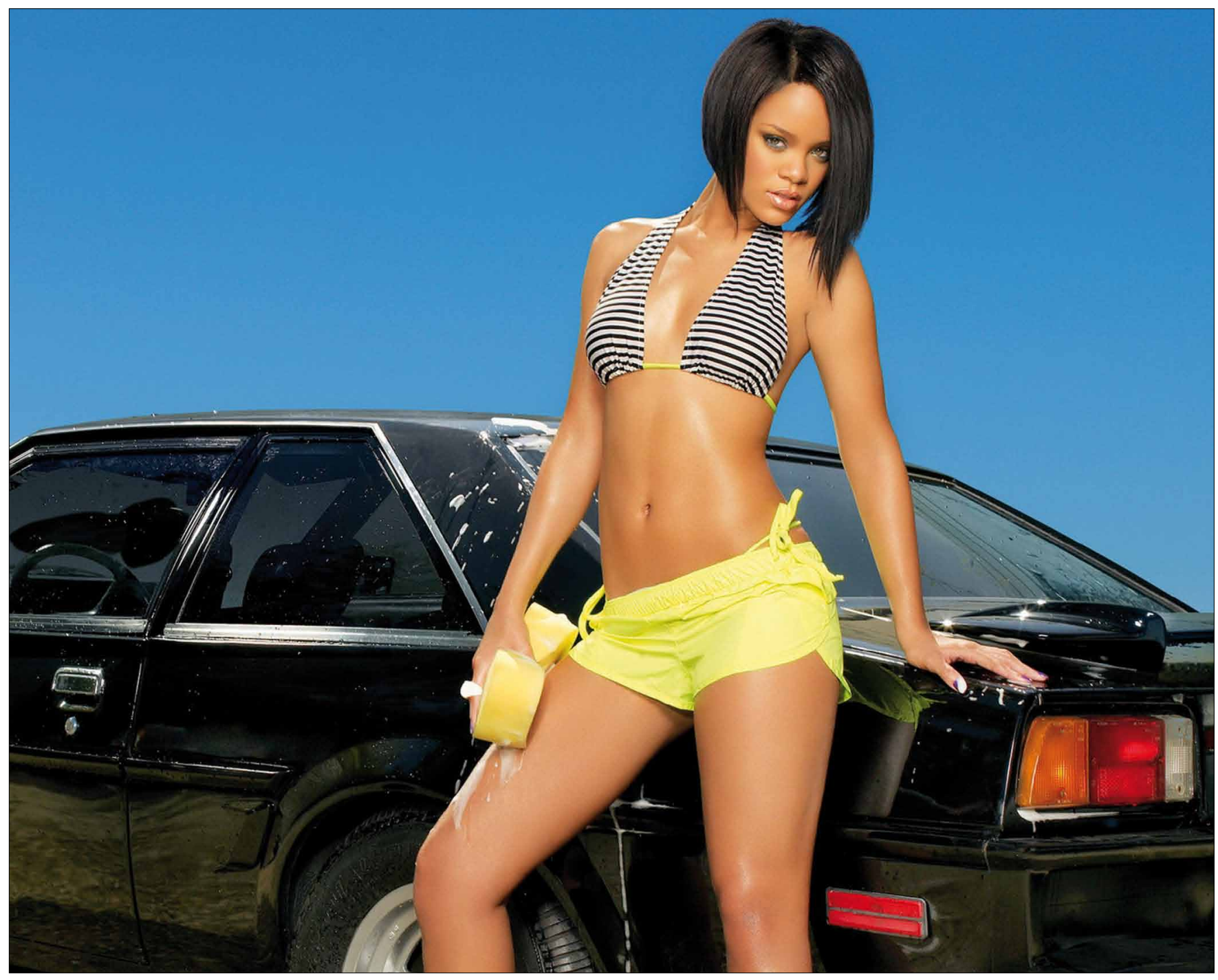

Obr. 15. Zpěvačka Rihanna. Zdroj: http://www.pulsarmedia.eu/data/media/707/Rihanna_Car.jpg

puje Car Music Project. Tato formace je spjatá zejména s hudebním skladatelem Billem Milbrodtem. Myšlenka využití automobilu $\mathrm{k}$ hudební reprodukci se u něj zrodila na konci roku 1991, když se loučil se svým starým a potlučeným automobilem Honda Accord. Slovy Milbrodta, která jsou uveřejněna na webových stránkách projektu (www.carmusicproject. com) zažil tento vůz téměř 200000 kilometrů na silnici s minimem mechanické údržby a kosmetických úprav. To by stálo mnohem víc, než aby se tyto investice vyplatily a automobil už neměl prakticky žádnou hodnotu, aby se mohl prodat. Lak byl oprýskaný, pružiny trčely přes čalounění, hlava řadicí páky chyběla, na elektrický systém se nešlo spolehnout. Z vozu kapal olej, vycházel z něj kouř a zvuk dělal ostřejší než míchačky na maltu a bylo tedy na čase přestavět automobil do hudby. Milbrodt tedy rozebral svůj starý automobil na díly, z nichž spolu se sochařem Rayem Fauncem III sestrojil několik hudebních nástrojů, přičemž tento náročný proces trval 18 měsíců. Nejrozměrnějším nástrojem orchestru se stala tzv. Percarsion - soustava perkusí obsahující brzdové pružiny, části náprav a kol, okna, písty a další součástky motoru. Dále mezi nástroji figuruje například trombon z části spojky, kontrabas vyrobený $z$ nádrže či „Air Guitar“ - kytara vytvořená z části klimatizace. Samotná hudební činnost skupiny Car Music Project byla zahájená počátkem roku 2005. Po řadě koncertů pak projekt sklidil největší úspěch svým vystoupením ve Filadelfii na festivalu Live Arts \& Fringe. Kapela rovněž 5. srpna 2007 vystupovala v prestižním newyorském Lincolnově centru, v současné době je však činnost uskupení pozastavena.

\section{ZÁVĚR}

Téma spojení hudby a automobilu není v této studii zcela vyčerpáno a nabízí prostor pro další výzkumy. S automobilem se setkáváme od raného dětství - je jednou ze základních dětských hraček, objevuje se $\mathrm{v}$ pohádkových př́bězích a samozřejmě vstupuje i do populárních dětských písniček. Proto by jedním ze zajímavých témat mohla být analýza tohoto fe- 
noménu. Dalším podnětem ke studiu by mohla být např́klad etymologie názvů hudebních kapel, které se ve svém pojmenování inspirovaly právě určitou značkou či typem automobilu. V neposlední řadě by mohlo být zajímavé sledovat, jakým způsobem jsou komponované nebo vybírané podkresové hudební motivy $\mathrm{k}$ reklamním spotům na jednotlivé značky automobilů. Prostor pro další zkoumání nabízí také fenomén hudby $\mathrm{v}$ autě, kterému je věnována první část této práce, a to jak z hlediska technických zlepšení, psychologického vlivu na řidiče, tak také $\mathrm{z}$ hlediska samotné hudební produkce např́iklad nejposlouchanější skladby v autě.

\section{LITERATURA}

Americký př́běh Bobby Troupa, autora slavné písně (2007). (online) http:// www.r66.cz/novinky/americky-pribeh-bobby-troupa-autora-slavne-pisne-95.html

Anderson, Philip (2001): Gary Numan - Numan Drives Music More Than Cars. (online) http://www.kaos2000.net/interviews/garynuman/

Brodsky, Warren (2001): The Efects of Music Tempo on Simulated Driving Performance and Vehicular Control. Transportation Research Part F: Traffic Psychology and Behaviour, 4(4), 219-241.

Davidson, Janet: Music and Mobility. (online) http://americanhistory.si.edu/ onthemove/themes/story_41_1.html

Diestler, Radek (2010) Tři sestry: 25 let ve 25 obrazech; plus 150 dábelských fotografí. Ritka: Daranus.

Foster, Richard S. (1973): A Nice Morning Drive. Road and Track Now. (online) http://www.2112.net/xanadu/articles/a_nice_morning_drive.htm

Franěk, Marek (2009): Hudební psychologie. Praha: Karolinum.

Gössel, Gabriel. Já mám automobil (I.). Týdeník Rozhlas [online]. 2004, č. 49 [cit. 2012-06-20]. Dostupné z: http://www.radioservis-as.cz/archiv04/4904/49pub3.htm

Gössel, Gabriel. Já mám automobil (II.). Týdeník Rozhlas [online]. 2004, č. 50 [cit. 2012-06-20]. Dostupné z: http://www.radioservis-as.cz/archiv04/5004/50pub3.htm

Gruber, Enid L. et al. (2005): Alcohol, Tobacco and Illicit Substances in Music Videos: A Content Analysis of Prevalence and Genre. Journal od Adolescent Health, 37(1), 81-83.

Havlík, Karel (2005): Psychologie pro řidiče. Praha: Portál.

Hillstron, Kevin - Hillstrom Laurie Collier (eds.) (2006): The Industrial Revolution in America: Automobiles. Santa Barbara: ABC-CLIO.

Juslin, Patrik - Sloboda, John A. (2001): Music and Emotion: Theory and Research. Oxford: Oxford University Press.

Karel Gott - Zlatý hlas z Prahy (auta) [online]. [cit. 2012-06-20]. Dostupné z: http://www.karelgott.net/prehledy/?men $=$ cs\&lang=cs\&id=19

KKK: Skákající auta. (online) http://www.stream.cz/kkk/625723-kkk-skakajici-auta

KKK: Klipy z jedoucího auta. (online) http://www.stream.cz/kkk/617954-kkk-klipy-z-jedouciho-auta

O Danovi. Daniel Landa [online]. [cit. 2012-06-20]. Dostupné z: http://www. daniel-landa.cz/o-danovi/

Procházka, Tomáš: Automobil. (online) http://www.hisvoice.cz/clanek_901_ tomas-prochazka-automobil.html

Robinson, Doug (2005): Shirley's had Fun, Fun, Fun with her 41 Years of „Fame“. Desert News. (online) http://www.deseretnews.com/article/625152574/Shirleys-had-fun-fun-fun-with-her-41-years-of-fame. html?pg=all
Rolls Royce brouka Johna Lennona. (online) http://www.autostylonline.cz/ zivot-za-volantem/rolls-royce-brouka-johna-lennona

Steinman, Jim (1999): Classic Albums: Meat Loaf Bat Out of Hell (DVD). Image Entertainment.

Wiesenthal, David L. - Hennessy, Dwight A. - Totten, Brad (2003): The Influence of Music on Mild Driver Aggression. Transportation Research Part F: Traffic Psychology and Behaviour, 6(2), 125-134.

Zkratky (píseň). In: Necyklopedie [online]. San Francisco (CA): Wikia, Inc, 2005- [cit. 2012-06-20]. Dostupné z: http://necyklopedie.wikia.com/ wiki/Zkratky_(p\%C3\%ADse\%C5\%88)

Webové stránky:

www.carmusicproject.com

\section{AUTORKY}

Poláková, Markéta (3. 5. 1983, Praha), kulturoložka, absolventka Katedry teorie kultury (kulturologie) Filozofické fakulty Univerzity Karlovy v Praze. Předmětem jejího výzkumného zájmu je problematika genderu a kultury v perspektivě feministické antropologie a Gender Studies. Stěžejním tématem jejích studií je analýza obrazu muže a ženy v současné západní společnosti. Zabývá se také analýzou vlivu médií a nových technologií na formování genderové identity. Diplomová práce (2007): Mužský a ženský princip v transkulturní perspektivě (gender, sexualita, kultura). Disertační práce (2011): Gender, identita, kultura. Od roku 2012 působí v oddělení Lokální a regionální studia Sociologického ústavu Akademie věd České republiky.

Kontakt: PhDr. Markéta Poláková, Ph.D., Lokální a regionální studia, Sociologický ústav Akademie věd České republiky, v.v.i., Jilská 1, 11000 Praha 1, e-mail: marketa.polakova@soc.cas.cz; marketa. polak@seznam.cz

Šeredová Purschová, Adéla (6. 3. 1978), kulturoložka, absolventka Katedry teorie kultury (kulturologie) Filozofické fakulty Univerzity Karlovy v Praze. V rámci své výzkumné činnosti se věnuje především dějinám kulturní a sociální antropologie s ohledem na problematiku pohlaví a genderu, genderovým aspektům ochrany životního prostředí, metodám prosazování genderové rovnosti a politice rovných př́ležitostí ve strukturálních fondech Evropské unie. Diplomová práce (2007): Feministická antropologie. Disertační práce (2010): Kultura a gender.

Kontakt: PhDr. Adéla Šeredová Purschová, Ph.D., Katedra kulturologie) Filozofické fakulty Univerzity Karlovy v Praze, Celetná 20, 11000 Praha 1, e-mail: a.purschova@seznam.cz.

\section{INSTITUCIONÁLNÍ AFILIACE}

Sociologický ústav AV ČR, v.v.i., Praha; Filozofická fakulta Univerzity Karlovy v Praze - Katedra teorie kultury (kulturologie).

Studie je publikována s podporou na dlouhodobý koncepční rozvoj výzkumné organizace RVO: 68378025 
